\title{
Diet, weight management, physical activity and Ovarian \& Breast Cancer Risk in women with BRCA1/2 pathogenic Germline gene variants: systematic review
}

Adriana M. Coletta ${ }^{1,2,3}$, Susan K. Peterson' ${ }^{1}$, Leticia A. Gatus ${ }^{1}$, Kate J. Krause ${ }^{4}$, Susan M. Schembre ${ }^{5}$, Susan C. Gilchrist ${ }^{6}$, Banu Arun', Y. Nancy You ${ }^{8}$, Miguel A. Rodriguez-Bigas ${ }^{8}$, Larkin L. Strong ${ }^{9}$, Karen H. Lü ${ }^{10}$ and Karen Basen-Engquist ${ }^{1 *}$ (D)

\begin{abstract}
Introduction: Women with pathogenic germline gene variants in BRCA1 and/or BRCA2 are at increased risk of developing ovarian and breast cancer. While surgical and pharmacological approaches are effective for riskreduction, it is unknown whether lifestyle approaches such as healthful dietary habits, weight management, and physical activity may also contribute to risk-reduction. We conducted a systematic review of evidence related to dietary habits, weight status/change, and physical activity on ovarian and breast cancer risk among women with BRCA1/2 pathogenic variants.

Methods: We searched Medline, EMBASE, CENTRAL, PubMed, and clinicaltrials.gov up to October 3, 2019. We identified 2775 records and included 21.

Results: There is limited evidence related to these factors and ovarian cancer risk. For breast cancer risk, evidence suggests higher diet quality, adulthood weight-loss of $\geq 10$ pounds, and activity during adolescence and youngadulthood may be linked with decreased risk. Higher meat intake and higher daily energy intake may be linked with increased risk.

Conclusions: There is not enough evidence to suggest tailored recommendations for dietary habits or weight management among women with BRCA1/2 pathogenic variants compared to the general population for ovarian and breast cancer risk-reduction, and physical activity recommendations should remain the same.
\end{abstract}

Keywords: BRCA, Breast Cancer, Ovarian Cancer, Diet, Physical activity, Weight

\section{Background}

The estimated risk up to 80 years of age for ovarian and breast cancer among women with BRCA1 and BRCA2 pathogenic germline gene variants is 44 and $72 \%$ respectively for $B R C A 1$ and 17 and $69 \%$ respectively for

\footnotetext{
* Correspondence: kbasenen@mdanderson.org

'Department of Behavioral Science, The University of Texas MD Anderson Cancer Center, P.O. Box 301439, Unit 1330, Houston, TX 77030-1439, USA

Full list of author information is available at the end of the article
}

BRCA2 [1]. Effective surgical and pharmacological approaches are available for risk-reduction, such as riskreducing surgery in the context of both breast and ovarian cancer, chemoprevention in the context of breast cancer, and oral contraceptive use in the context of ovarian cancer $[2,3]$. What is currently unknown is whether complementary lifestyle approaches such as dietary habits, weight management, and physical activity

(c) The Author(s). 2020 Open Access This article is licensed under a Creative Commons Attribution 4.0 International License, which permits use, sharing, adaptation, distribution and reproduction in any medium or format, as long as you give appropriate credit to the original author(s) and the source, provide a link to the Creative Commons licence, and indicate if changes were made. The images or other third party material in this article are included in the article's Creative Commons licence, unless indicated otherwise in a credit line to the material. If material is not included in the article's Creative Commons licence and your intended use is not permitted by statutory regulation or exceeds the permitted use, you will need to obtain permission directly from the copyright holder. To view a copy of this licence, visit http://creativecommons.org/licenses/by/4.0/ The Creative Commons Public Domain Dedication waiver (http://creativecommons.org/publicdomain/zero/1.0/) applies to the data made available in this article, unless otherwise stated in a credit line to the data. 
(PA) may also contribute to cancer risk-reduction among this group of high-risk women.

To date, there are five reviews evaluating the impact of either dietary habits, weight management, or PA, or a combination of only two of these factors (i.e. diet and weight), on ovarian and/or breast cancer risk among women with $B R C A 1 / 2$ pathogenic germline gene variants from 1997 to 2015 [3-7]. Four of the five previous reviews included women with BRCA1 and BRCA2 pathogenic germline gene variants, but only in the context of breast cancer risk [3,5-7]. And only one review assessed ovarian cancer risk, and this was only in relation to alcohol intake [6]. No studies have exclusively evaluated healthful dietary habits, weight management, and PA together as they relate to both ovarian and breast cancer risk in this high-risk population.

The purpose of the current systematic review was to explore the state of evidence related to these lifestyle factors and ovarian and breast cancer risk among women with $B R C A 1 / 2$ pathogenic germline gene variants, in order to determine the extent to which lifestyle recommendations should differ compared to the general population.

\section{Methods}

\section{Search strategy}

The search terms and search strategy were developed by four authors (AMC, LG, KBE, KJK), one of whom (KJK) is a medical research librarian specializing in systematic reviews. A systematic search was performed in MEDLINE, EMBASE, Cochrane Library, and ClinicalTrials. gov from inception to October 3, 2019. Search structures, subject headings, and keywords were tailored to each database by KJK. The search was expanded through citation chaining (forward and backward) of included studies. The search terms used can be found in the MEDLINE search strategy [see Additional File 1]. Findings are reported in accordance with the Preferred Reporting Items for Systematic Reviews and MetaAnalyses (PRISMA) checklist [8](Fig. 1). The protocol is registered in PROSPERO(ID:CRD42017060007).

\section{Review process, selection Criteria \& Data Extraction}

Two authors (AMC, LG) independently screened the titles and abstracts of the articles to identify potentially relevant studies. Studies that passed the title/abstract review were retrieved for full-text review. Disagreements were resolved by consensus and by seeking the opinion of a third author (KBE). Inclusion criteria consisted of studies that: included individuals with $B R C A 1 / 2$ pathogenic germline gene variants; evaluated weight status, weight change, dietary habits (as defined by dietary patterns, food and beverage intake, multivitamin and mineral supplementation), or physical activity in relation to ovarian or breast cancer risk; published in English; and included human subjects only.

\section{Risk-of-Bias assessment}

The Quality Assessment Tool for Quantitative Studies, version 2010, was used for risk-of-bias assessment [9, 10]. Six components were evaluated to determine overall study quality: selection bias, design, confounders, blinding, data collection method, withdrawals/dropouts. Quality scores were assigned per criteria described elsewhere [10].

\section{Analysis}

Qualitative synthesis of data is provided in narrative form. A meta-analysis was not conducted due to the limited number of studies and heterogeneity in study design and outcome measures.

\section{Results}

Risk-of-Bias summary

Table 1 provides details of the risk of bias assessment for all studies. Four studies received an overall quality score of strong [11-14], 16 received moderate [15-29], and one received weak [30].

\section{Ovarian Cancer risk}

Table 2 provides study characteristics and results of the studies reviewed for both ovarian and breast cancer. Gronwald and colleagues [30] case-control study did not observe a significant association between coffee consumption and ovarian cancer risk (OR 0.7, 95\%CI 0.4, 1.3) among 348 women with $B R C A 1$ pathogenic germline gene variant [30]. Information regarding quantity of coffee consumed or statistical adjustments was not provided. No studies assessed PA.

Regarding weight status and weight change, after adjusting for age at menarche, parity, oral contraceptives, height, and hormone replacement therapy, McGee and colleagues [21] case-control study did not observe a significant association between current weight status or weight change throughout adulthood and diagnosis of ovarian cancer among 403 women with $B R C A 1$ and 66 women with $B R C A 2$ pathogenic germline gene variants. Risk was not assessed by $B R C A 1 / 2$ pathogenic germline gene variants individually. In contrast, Qian and colleagues [28] case-control study observed significant associations between a higher body mass index (BMI) and premenopausal ovarian cancer incidence, for both selfreported BMI (among 102 cases out of 7516 women with $B R C A 1 / 2$ pathogenic germline gene variants) and a calculated BMI genetic score (BMI-GS; among 967 cases out of 22,588 women with $B R C A 1 / 2$ pathogenic germline gene variants) based on a Mendelian Randomization approach. Higher self-reported BMI was also associated 


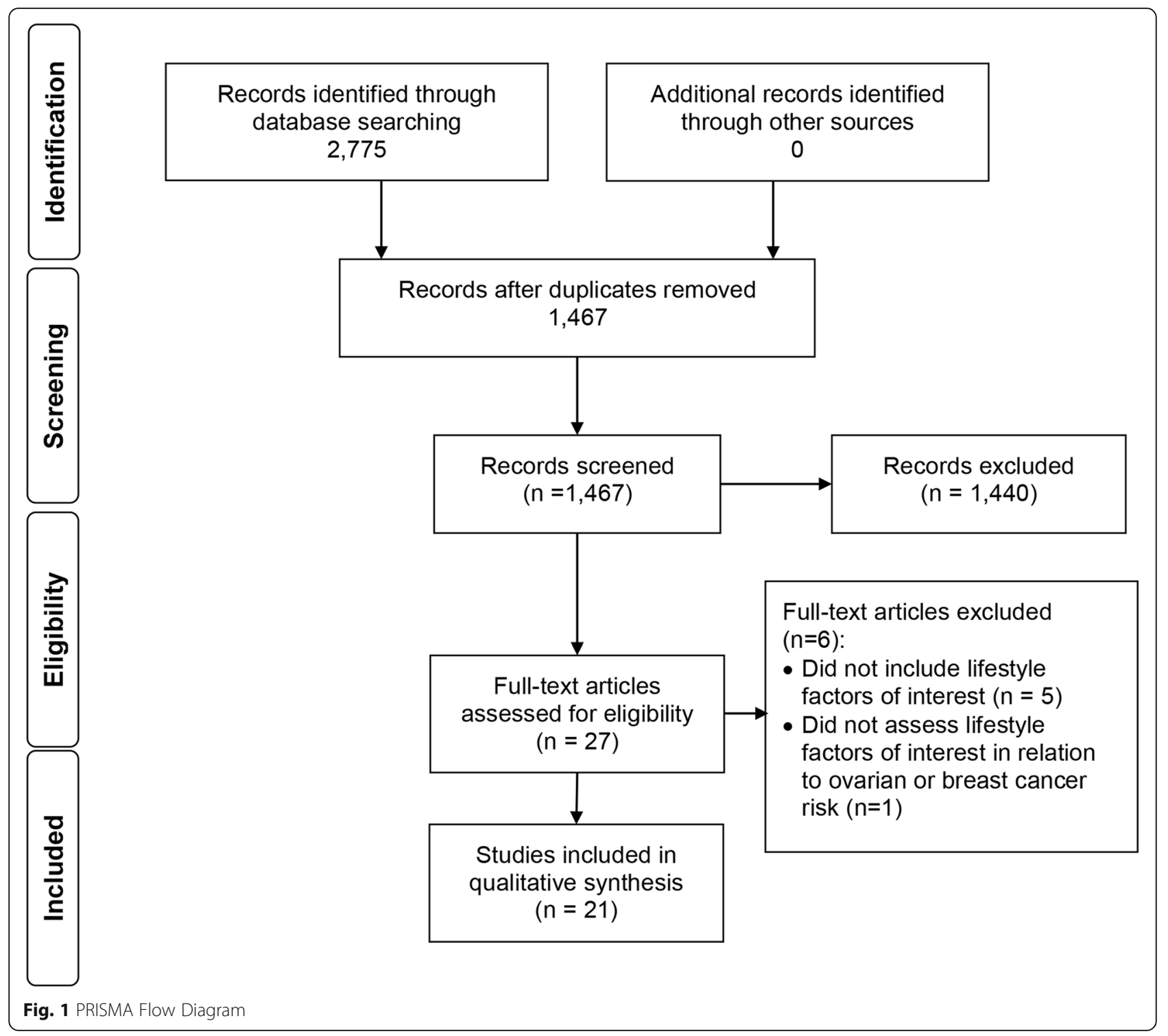

with increased risk of non-serous ovarian tumors [28]. Significant associations were not observed by BRCA1/2 pathogenic germline gene variants, postmenopausal status, or serous tumor type [28].

\section{Breast Cancer risk}

\section{Dietary habits-alcohol consumption}

Regarding women with BRCA1 pathogenic germline gene variants In Dennis and colleagues [16] case-control study, higher alcohol consumption was associated with reduced risk ( $\mathrm{p}$-trend $=0.03, n=1480$ ), after adjusting for ethnicity, parity, BMI, history of oral contraceptive use, hormone replacement therapy, oophorectomy, smoking and menopausal status. Compared to nondrinkers, 0-3 drinks/week (OR 0.77, 95\%CI 0.67,0.94) and $\geq 10$ drinks/week (OR 0.55, 95\%CI 0.33,0.91), but not 4-9 drinks/week (OR 0.98, 0.73,1.32), were significantly associated with reduced breast cancer risk [16].

In contrast, case-control studies by both Lecarpentier and colleagues [19] $(n=863$, adjusted for parity, menopausal status, $B R C A 1 / 2$ pathogenic germline gene variant, smoking history) and McGuire and colleagues [22] ( $n=497$, adjusted for age, family history, smoking status, and full-term pregnancies), and a prospective cohort study by Cybulski and colleagues [15] ( $n=2498$ adjusted for baseline age, gene, menarche age, oral contraceptive use, breast feeding history, mean parity, oophorectomy status, and resident country) did not observe significant associations between alcohol intake and breast cancer risk among women with $B R C A 1$ pathogenic germline gene variant. Similarly, Moorman and colleagues [23] case-only study observed a significant, but weak effect of alcohol intake among 283 breast cancer survivors with 
Table 1 Risk of Bias Summary

\begin{tabular}{|c|c|c|c|c|c|c|c|c|}
\hline $\begin{array}{l}\text { Cancer } \\
\text { Type }\end{array}$ & Author, Year & $\begin{array}{l}\text { Selection } \\
\text { Bias }\end{array}$ & $\begin{array}{l}\text { Study } \\
\text { Design }\end{array}$ & Confounders & Blinding & $\begin{array}{l}\text { Data Collection } \\
\text { Method }\end{array}$ & $\begin{array}{l}\text { Withdrawals \& } \\
\text { Dropouts }\end{array}$ & $\begin{array}{l}\text { Quality } \\
\text { Score }\end{array}$ \\
\hline \multirow{4}{*}{$\begin{array}{l}\text { Ovarian } \\
\text { Cancer }\end{array}$} & Gronwald J et al., 2006 & Strong & Moderate & Weak & N/A & Weak & N/A & Weak \\
\hline & McGee J et al., 2012 & Weak & Moderate & Strong & N/A & Moderate & N/A & Moderate \\
\hline & Qian F et al., 2019 & Strong & Moderate & Strong & N/A & Weak & N/A & Moderate \\
\hline & Abbas S et al., 2019 & Strong & Moderate & Weak & N/A & Strong & N/A & Moderate \\
\hline \multirow{18}{*}{$\begin{array}{l}\text { Breast } \\
\text { Cancer }\end{array}$} & Cybulski C et al., 2015 & Strong & Moderate & Strong & N/A & Weak & N/A & Moderate \\
\hline & Dennis J et al., 2010 & Strong & Moderate & Strong & N/A & Moderate & N/A & Moderate \\
\hline & Dennis J et al., 2011 & Strong & Moderate & Strong & N/A & Strong & N/A & Strong \\
\hline & Gronwald J et al., 2006 & Strong & Moderate & Weak & N/A & Weak & N/A & Weak \\
\hline & Kim SJ et al., 2019 & Strong & Moderate & Strong & N/A & Moderate & N/A & Moderate \\
\hline & King MC et al., 2003 & Strong & Moderate & Moderate & N/A & Weak & N/A & Moderate \\
\hline & Ko KP et al., 2013 & Strong & Moderate & Strong & N/A & Strong & N/A & Strong \\
\hline & Kotsopoulos J et al., 2005 & Moderate & Moderate & Strong & N/A & Moderate & N/A & Moderate \\
\hline & Lammert J et al., 2018 & Strong & Moderate & Strong & N/A & Strong & N/A & Strong \\
\hline & Lecarpentier J et al., 2011 & Strong & Moderate & Strong & N/A & Moderate & N/A & Moderate \\
\hline & Manders P et al., 2011 & Strong & Moderate & Strong & N/A & Weak & N/A & Moderate \\
\hline & McGuire V et al., 2006 & Moderate & Moderate & Strong & N/A & Moderate & N/A & Moderate \\
\hline & Moorman PG et al., 2010 & Strong & Moderate & Weak & N/A & Moderate & N/A & Moderate \\
\hline & $\begin{array}{l}\text { Nkondjock A, Ghadirian P, } \\
\text { et al., } 2006\end{array}$ & Strong & Moderate & Strong & N/A & Moderate & N/A & Moderate \\
\hline & $\begin{array}{l}\text { Nkondjock A, Robidoux A } \\
\text { et al., } 2006\end{array}$ & Moderate & Moderate & Strong & N/A & Strong & N/A & Moderate \\
\hline & Nkondjock A et al., 2007 & Strong & Moderate & Strong & N/A & Strong & N/A & Strong \\
\hline & Pijpe A et al., 2010 & Moderate & Moderate & Strong & N/A & Moderate & N/A & Moderate \\
\hline & Qian F et al., 2019 & Strong & Moderate & Strong & N/A & Weak & N/A & Moderate \\
\hline
\end{tabular}

$B R C A 1$ pathogenic germline gene variant compared to 891 survivors without $B R C A 1$ pathogenic germline gene variant (interaction risk ratio(IRR) $0.65,95 \% \mathrm{CI} 0.48,0.90$ ) when adjusting for age and site of data collection. In Dennis and colleagues [11] case-only study (adjusted for age at diagnosis) that included 10 women with $B R C A 1$ pathogenic germline gene variants, significant interactions were not observed (case-only odds ratio(COR) $0.79,95 \%$ CI $0.22,2.83)$.

Regarding women with $B R C A 2$ pathogenic germline gene variants, McGuire and colleagues [22] observed an association with ever-use of alcohol compared to neveruse (OR 0.66, 95\%CI 0.45,0.97), and 1-4 g/day compared to no alcohol (OR 0.41, 95\%CI 0.22,0.77), among 307 women with $B R C A 2$ pathogenic germline gene variants. Associations were not observed for other alcohol variables (i.e. $>4 \mathrm{~g} /$ day, current use, years of drinking). Dennis and colleagues [11] observed a supra-multiplicative effect for all alcohol excluding wine, among 33 cancer survivors with $B R C A 2$ pathogenic germline gene variant compared to 814 survivors without $B R C A 2$ pathogenic germline gene variant (COR 2.15, 95\%CI 1.03,4.49); effects were not observed for all alcohol including wine, or wine alone [11]. In contrast, other studies did not observe effects among women with BRCA2 pathogenic germline gene variant $[15,19,23]$.

\section{Dietary habits-coffee consumption}

In Gronwald and colleagues [30] case-control study, no association was observed between coffee consumption and breast cancer risk among 348women with BRCA1 pathogenic germline gene variant (OR $0.8,95 \% \mathrm{CI} 0.5$, 1.1). Amount of coffee consumption and statistical adjustments for the analysis were not specified. In contrast, Nkondjock and colleagues [24] case-control study observed an association between $\geq 6$ cups caffeinated coffee/day among 652women with BRCA1 pathogenic germline gene variant and breast cancer risk (OR 0.25, 95\%CI 0.09,0.71). Associations were not observed for women with $B R C A 2$ pathogenic germline gene variant ( $n=193)$. When assessing BRCA1/2 pathogenic germline gene variants collectively, $\geq 6$ cups/day of total coffee (caffeinated and decaffeinated; OR $0.51,95 \% \mathrm{CI} 0.26$, 0.98 ) and $\geq 6$ cups/day of caffeinated coffee (OR 0.31, 


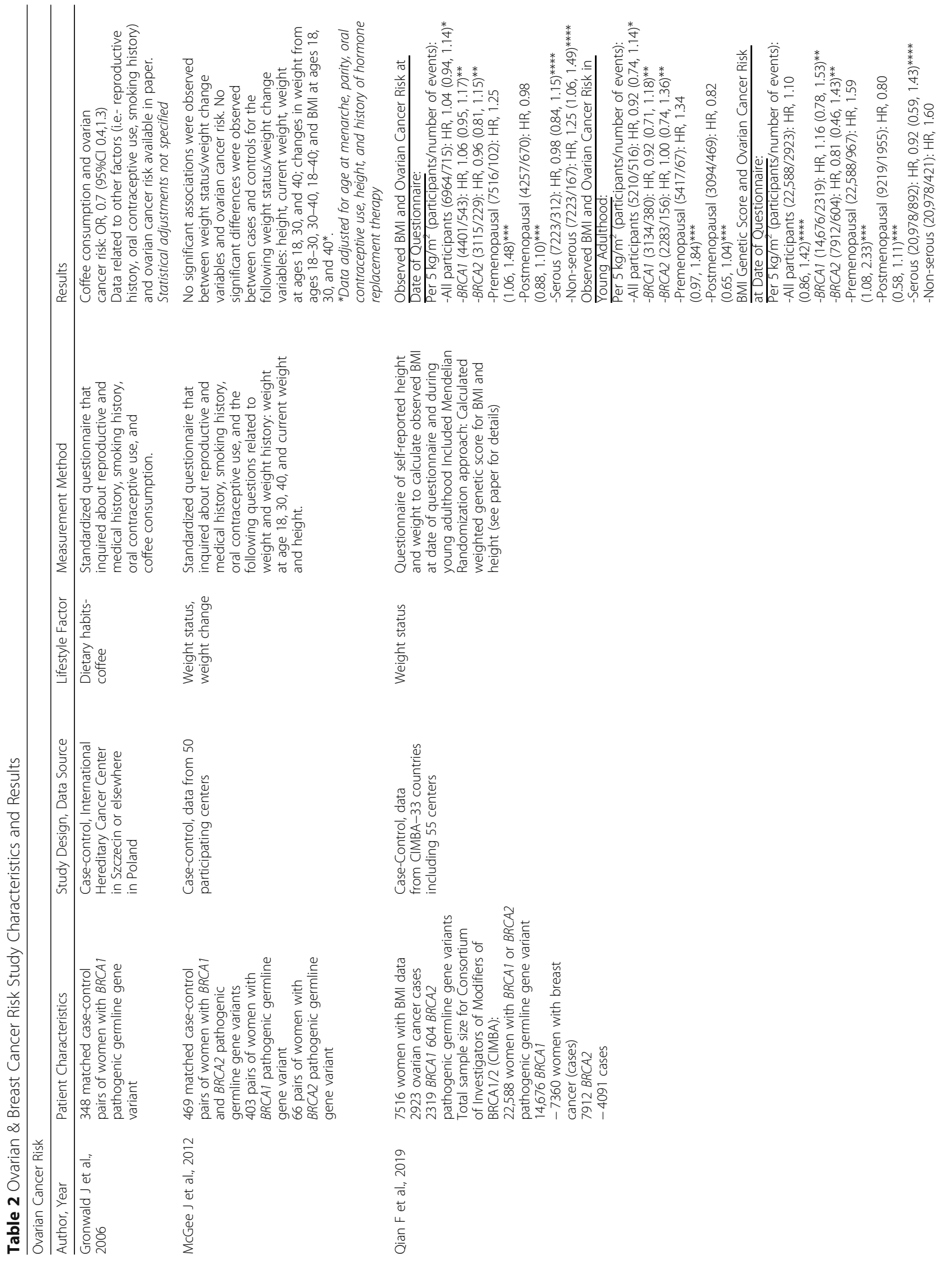




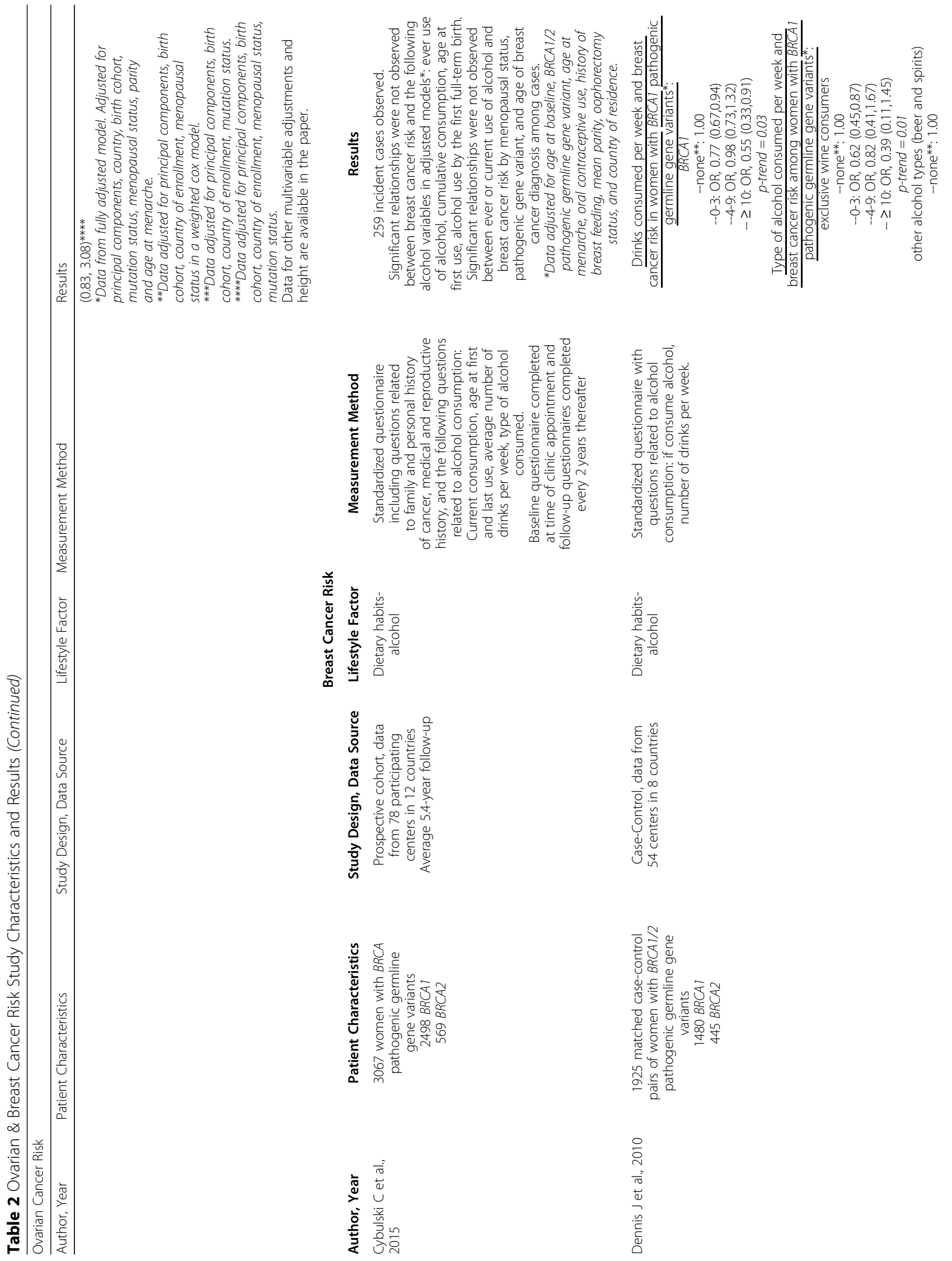




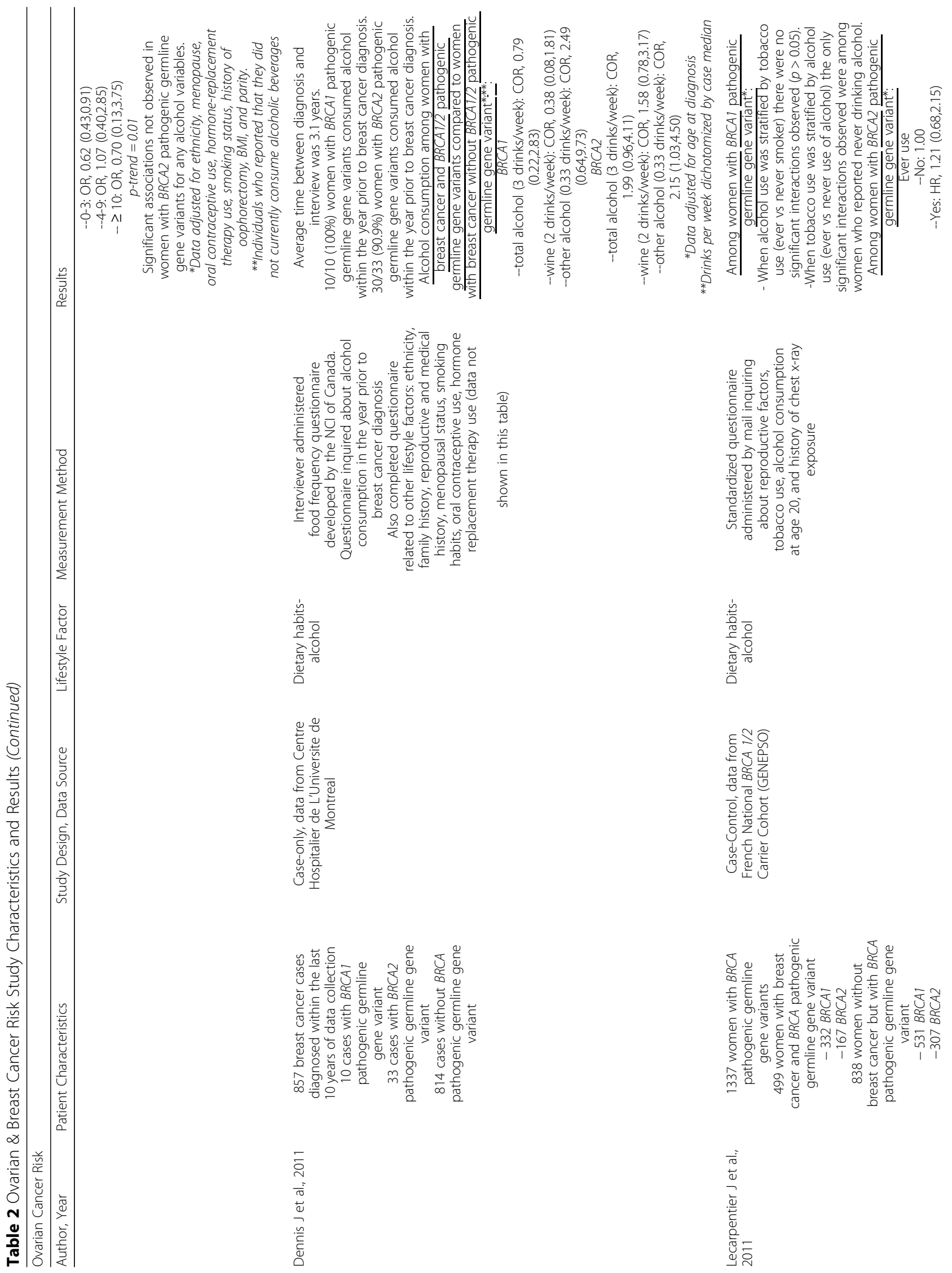




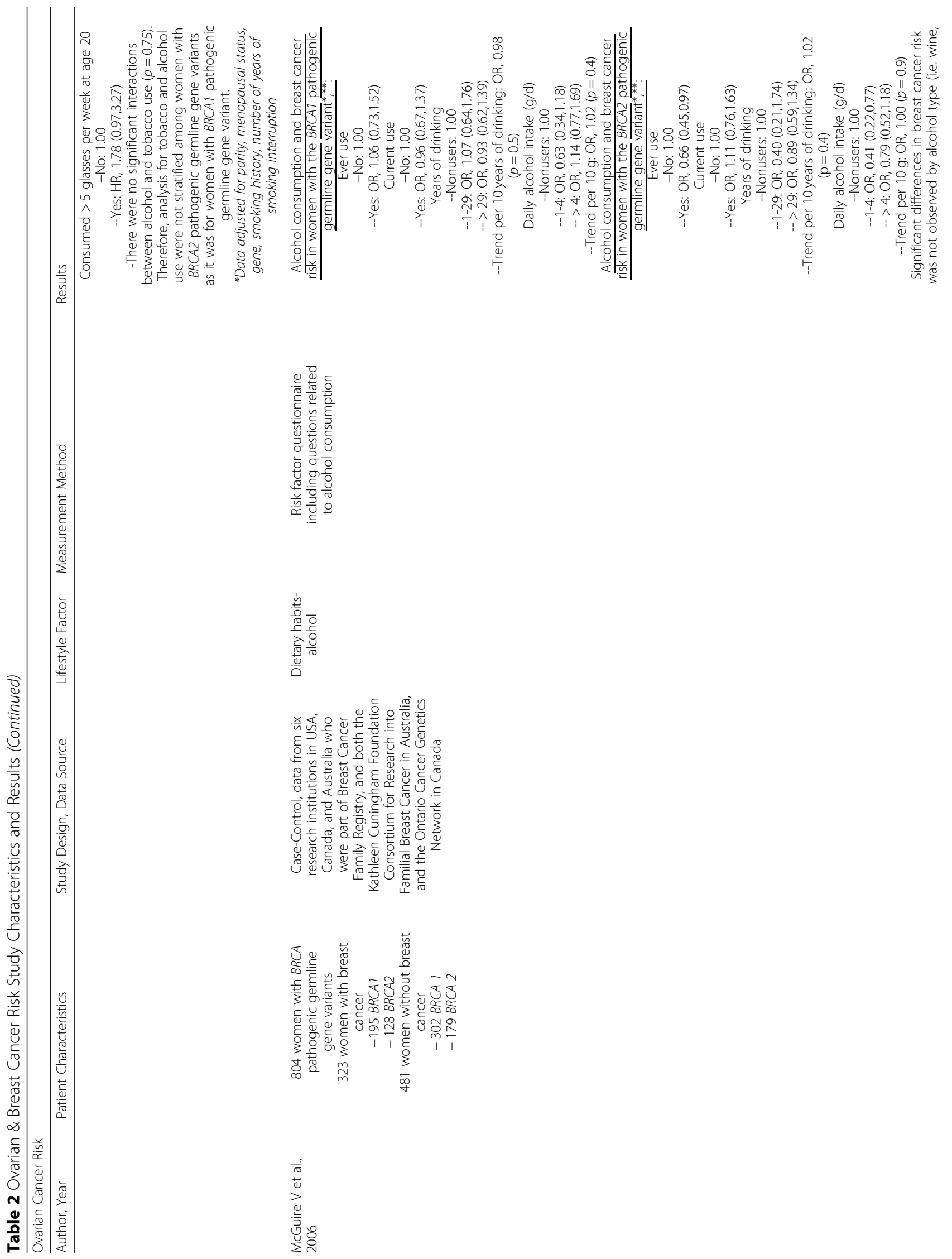


Colette et al. Hereditary Cancer in Clinical Practice

(2020) 18:5

Page 9 of 24

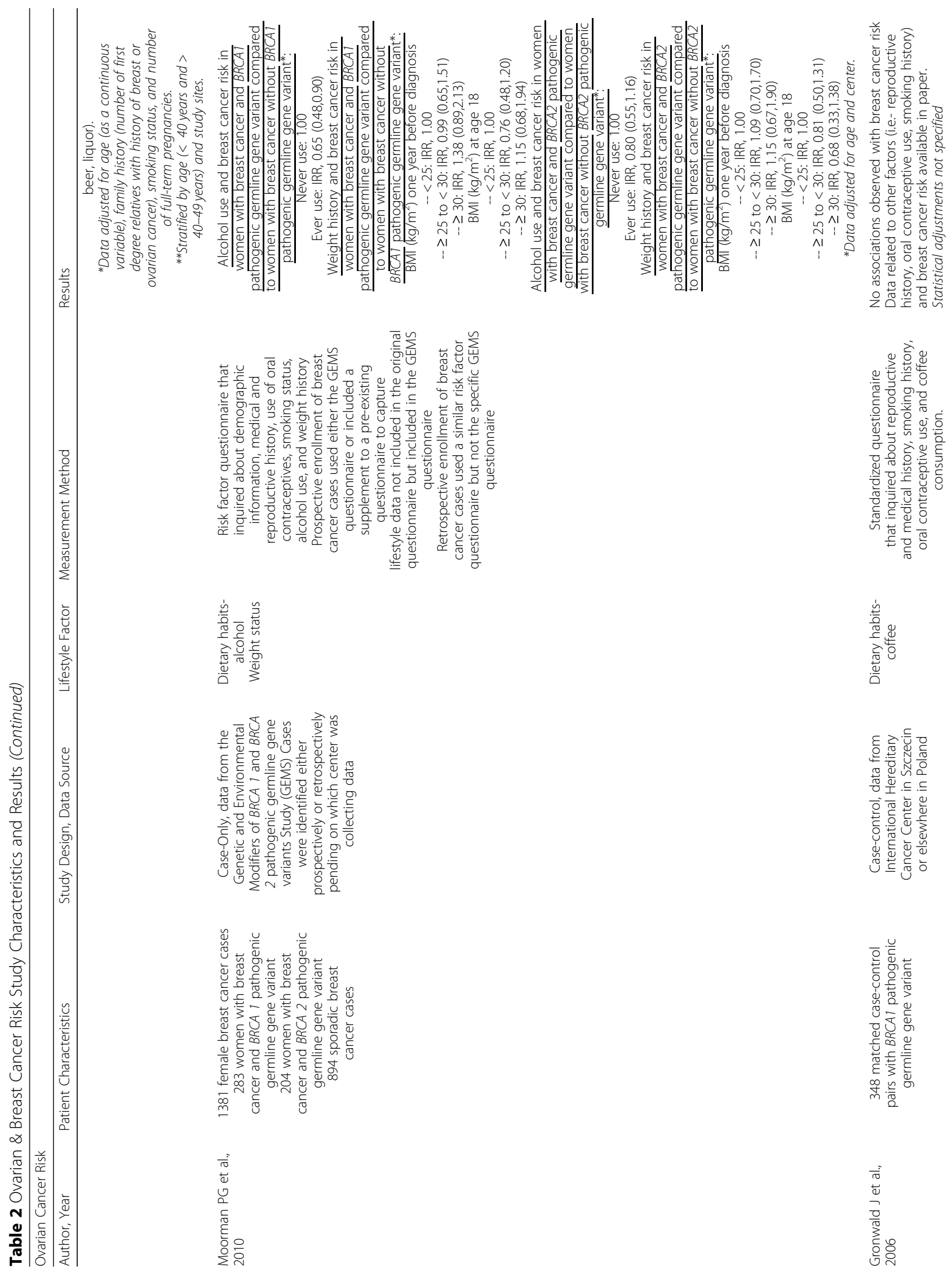




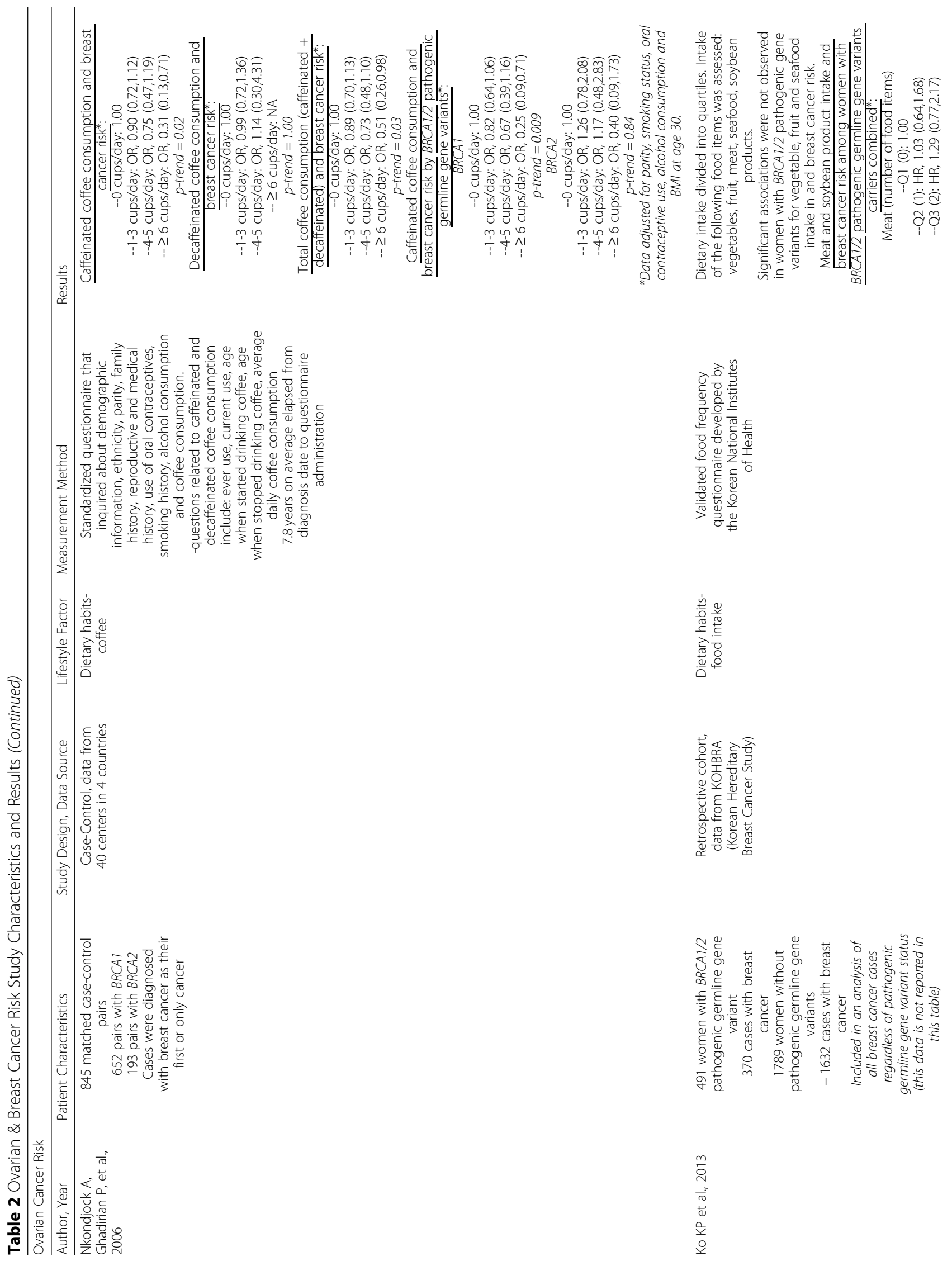




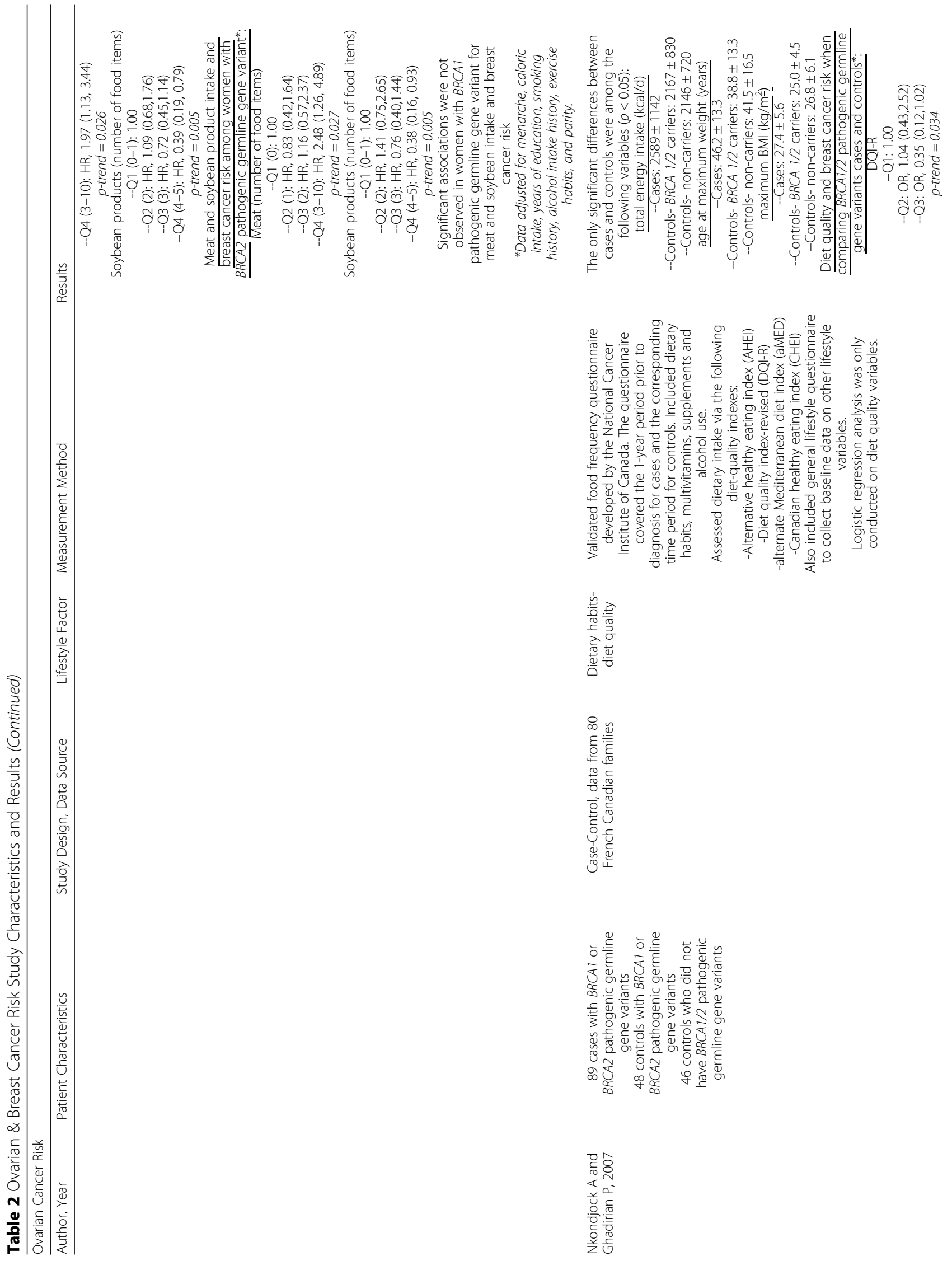




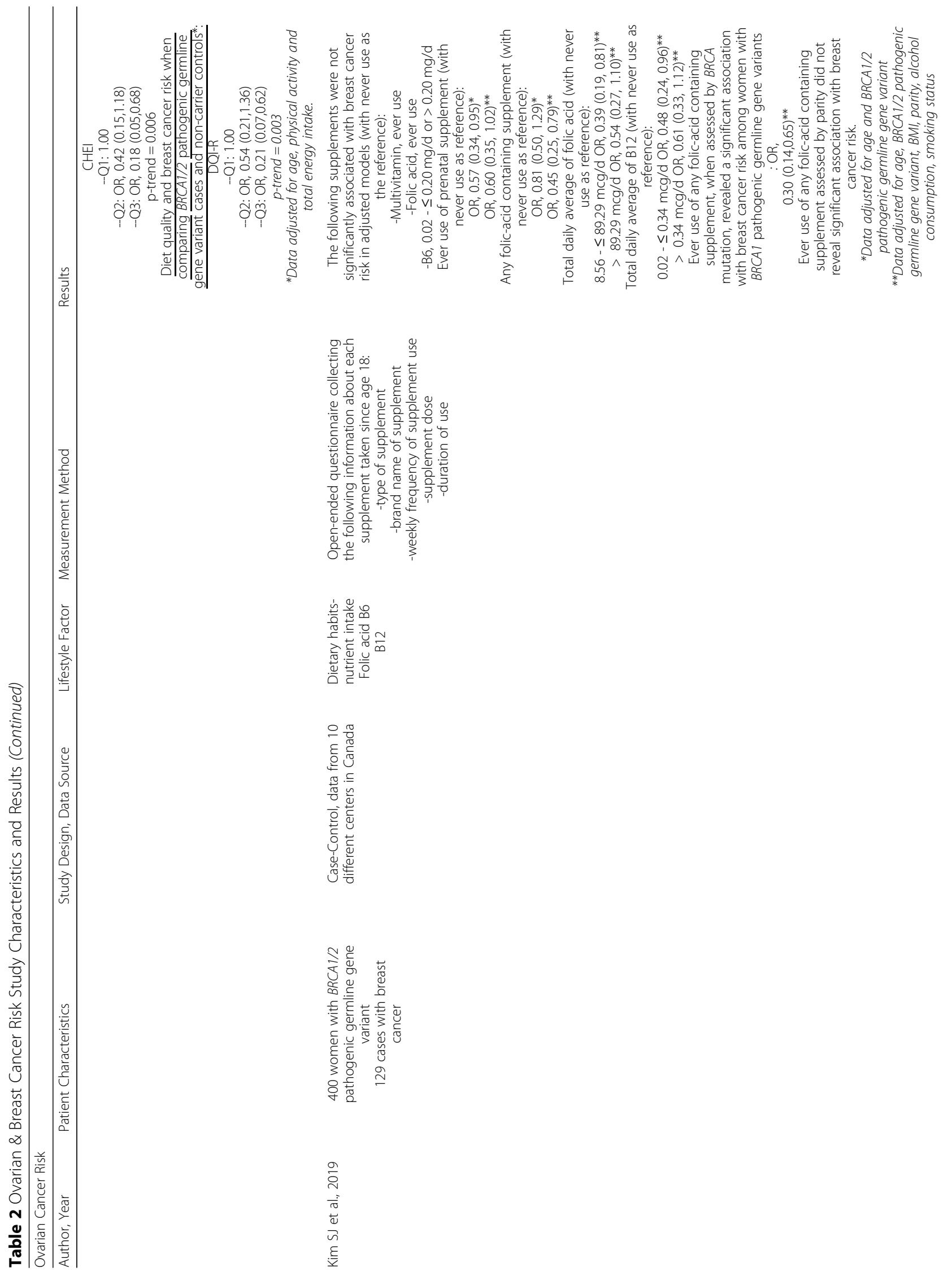




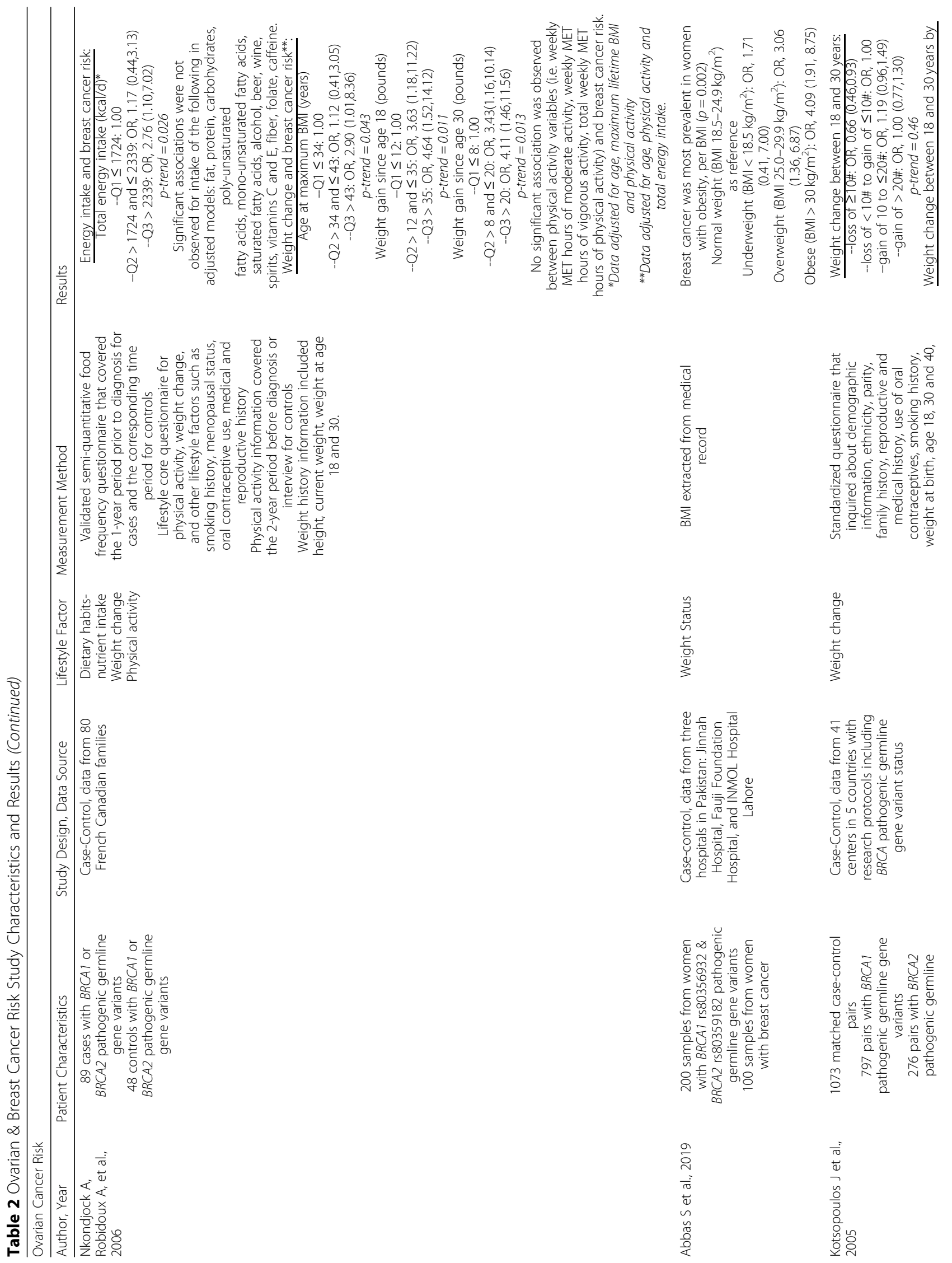




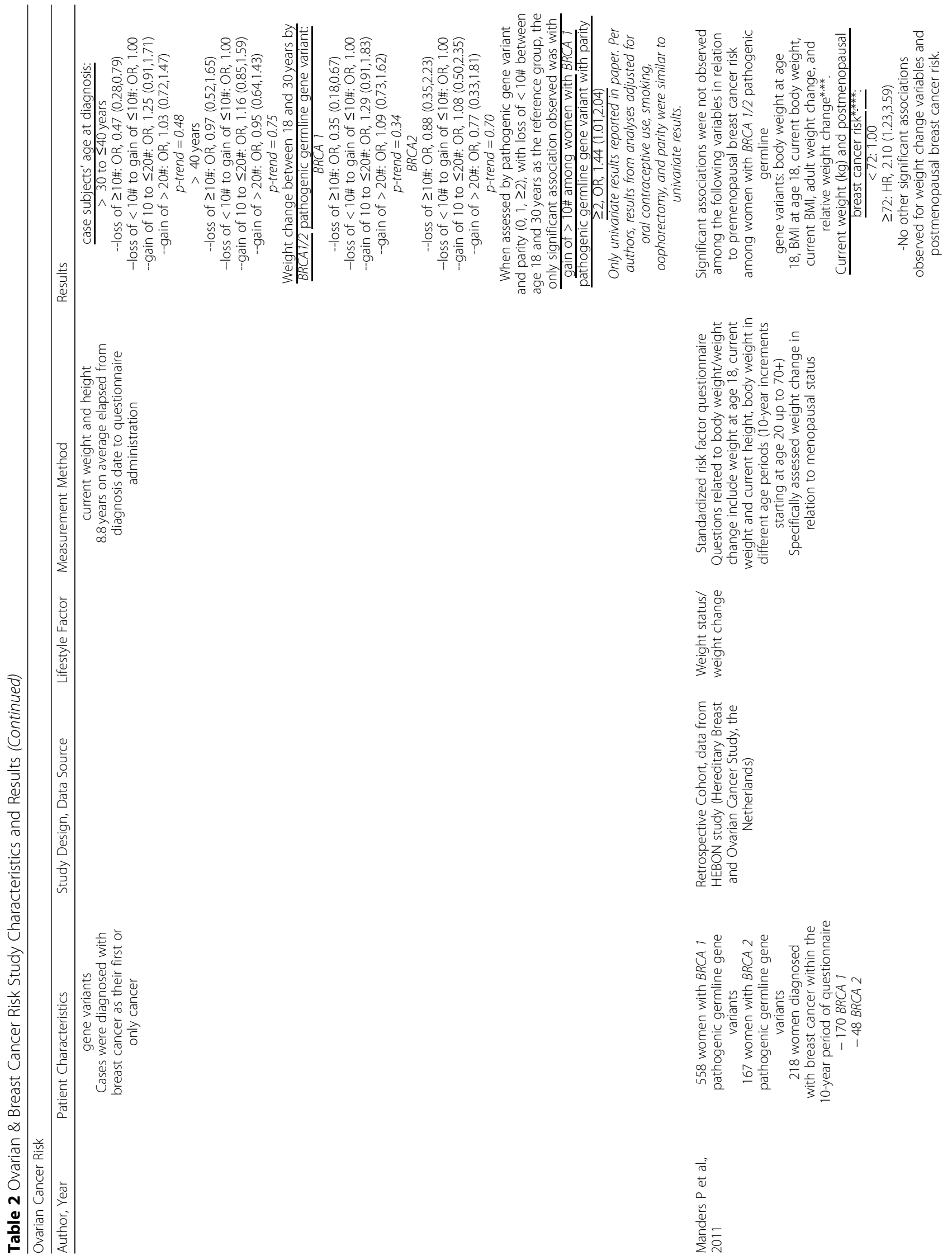




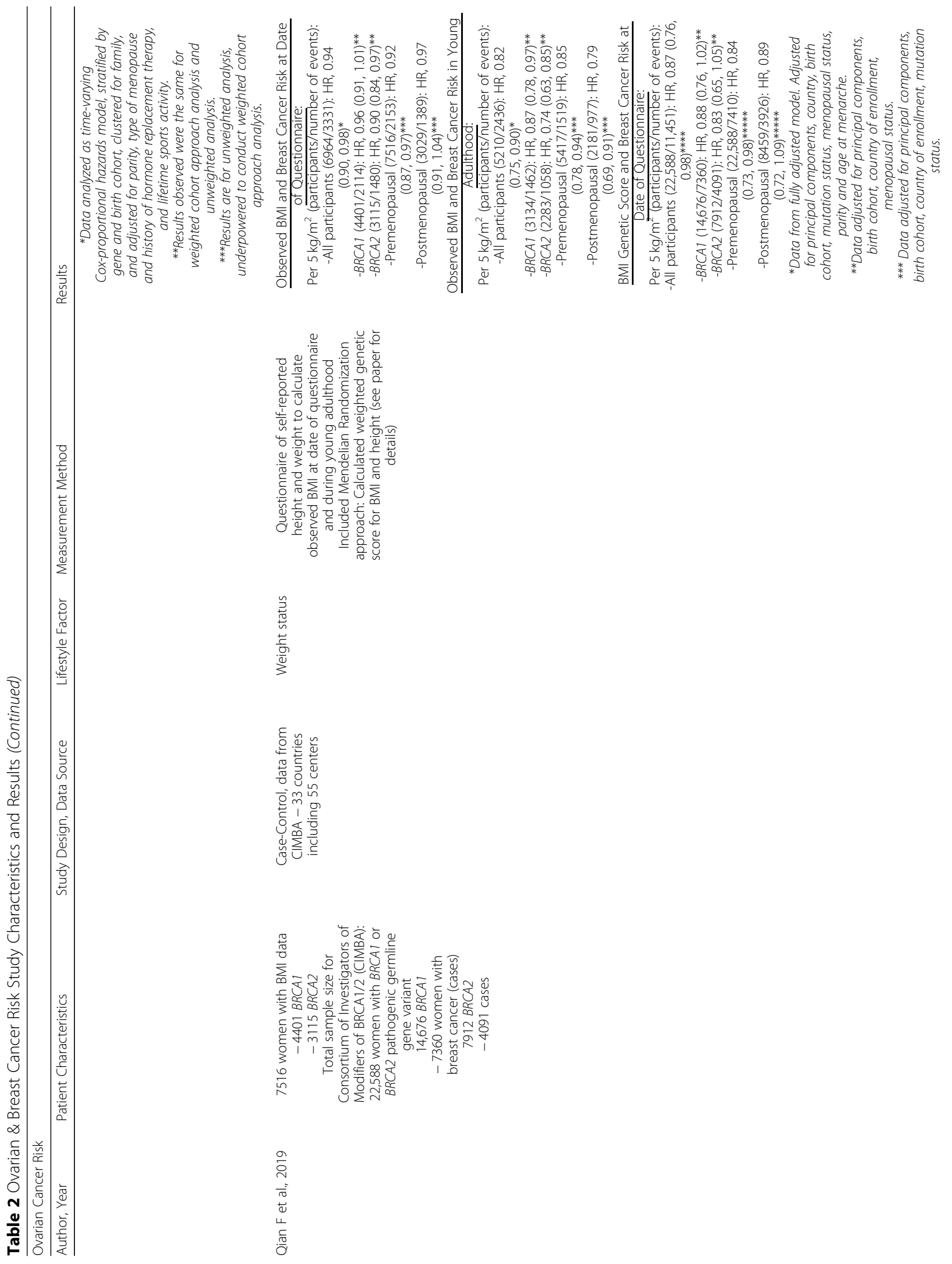




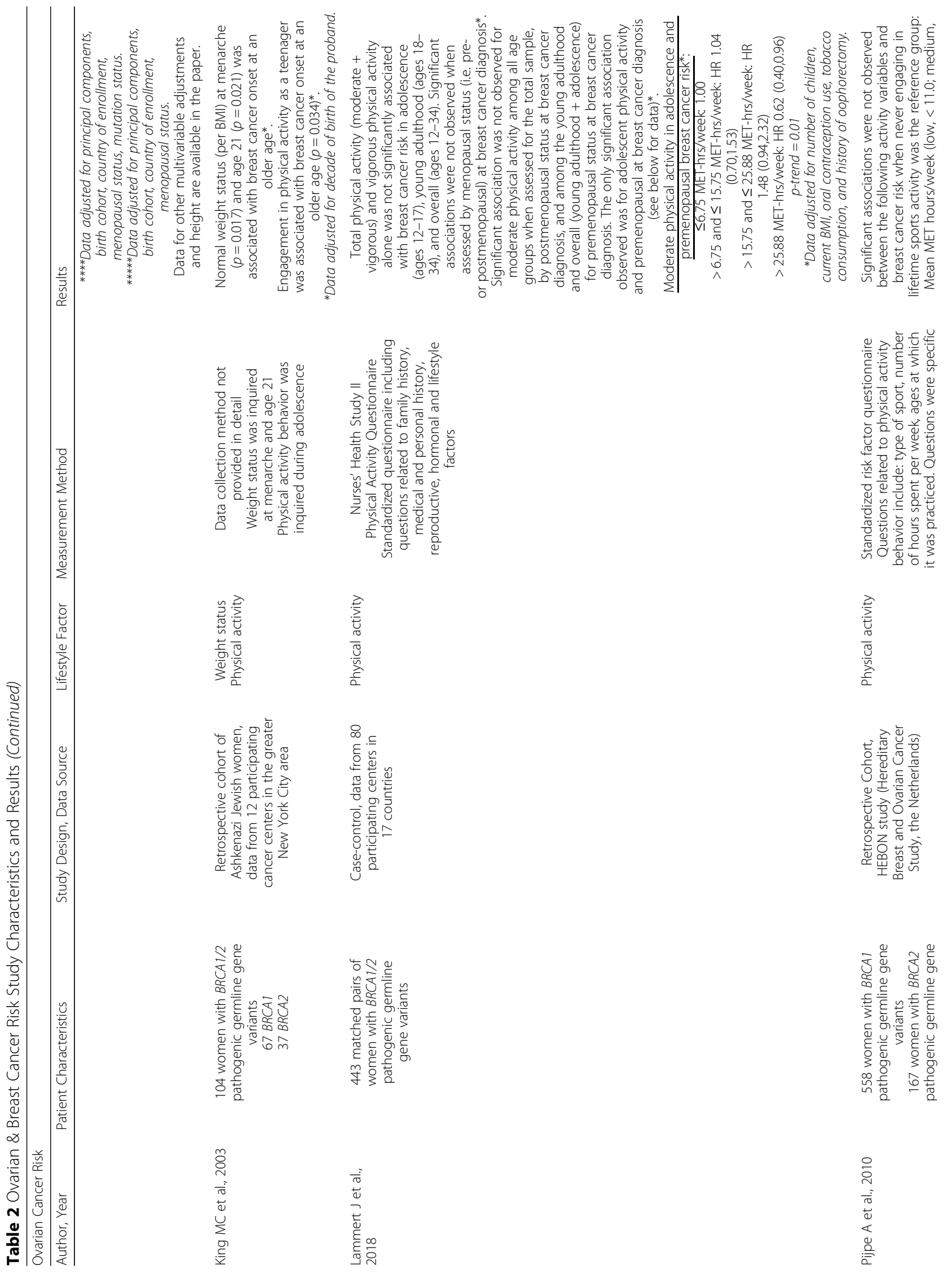




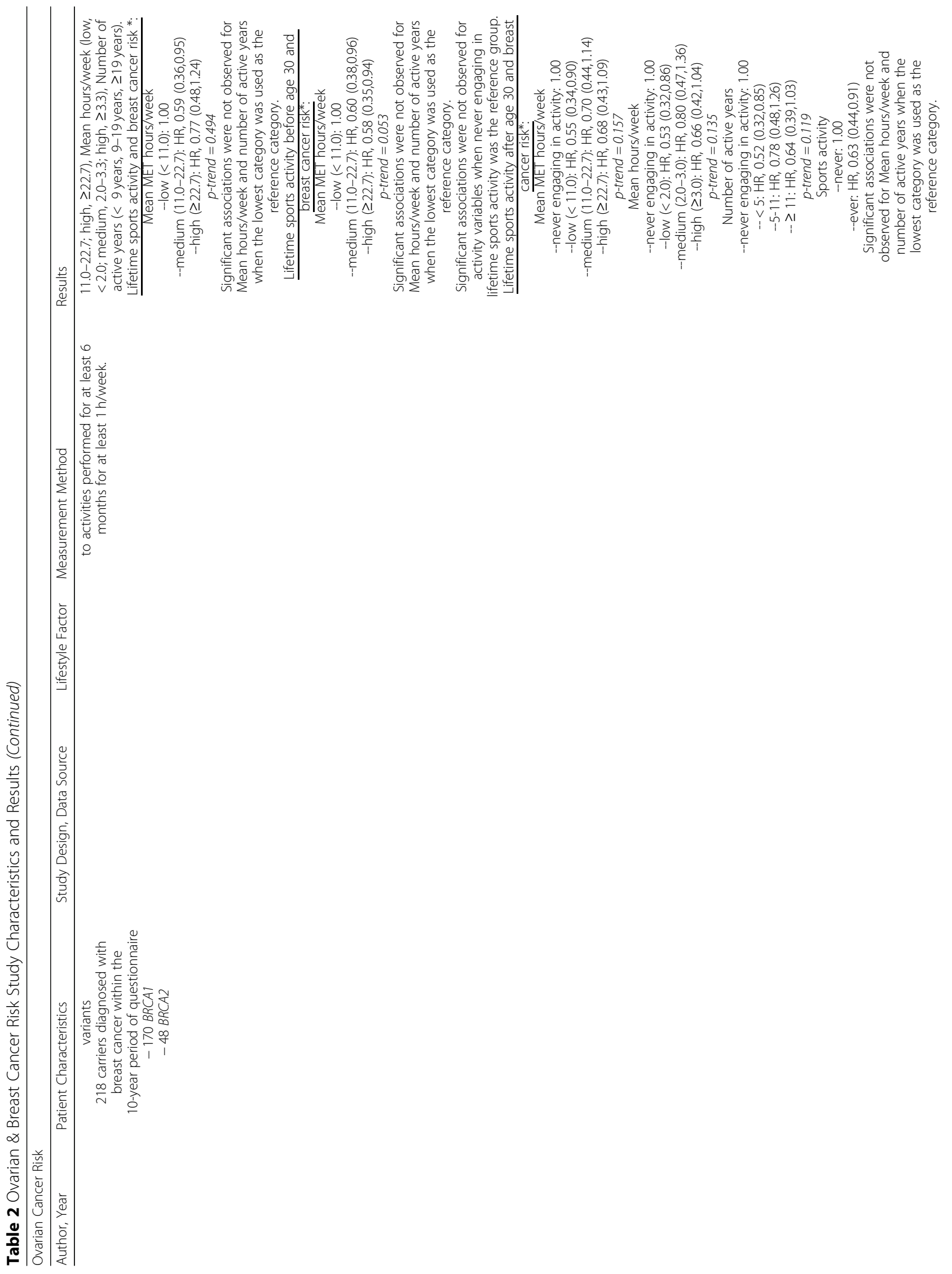




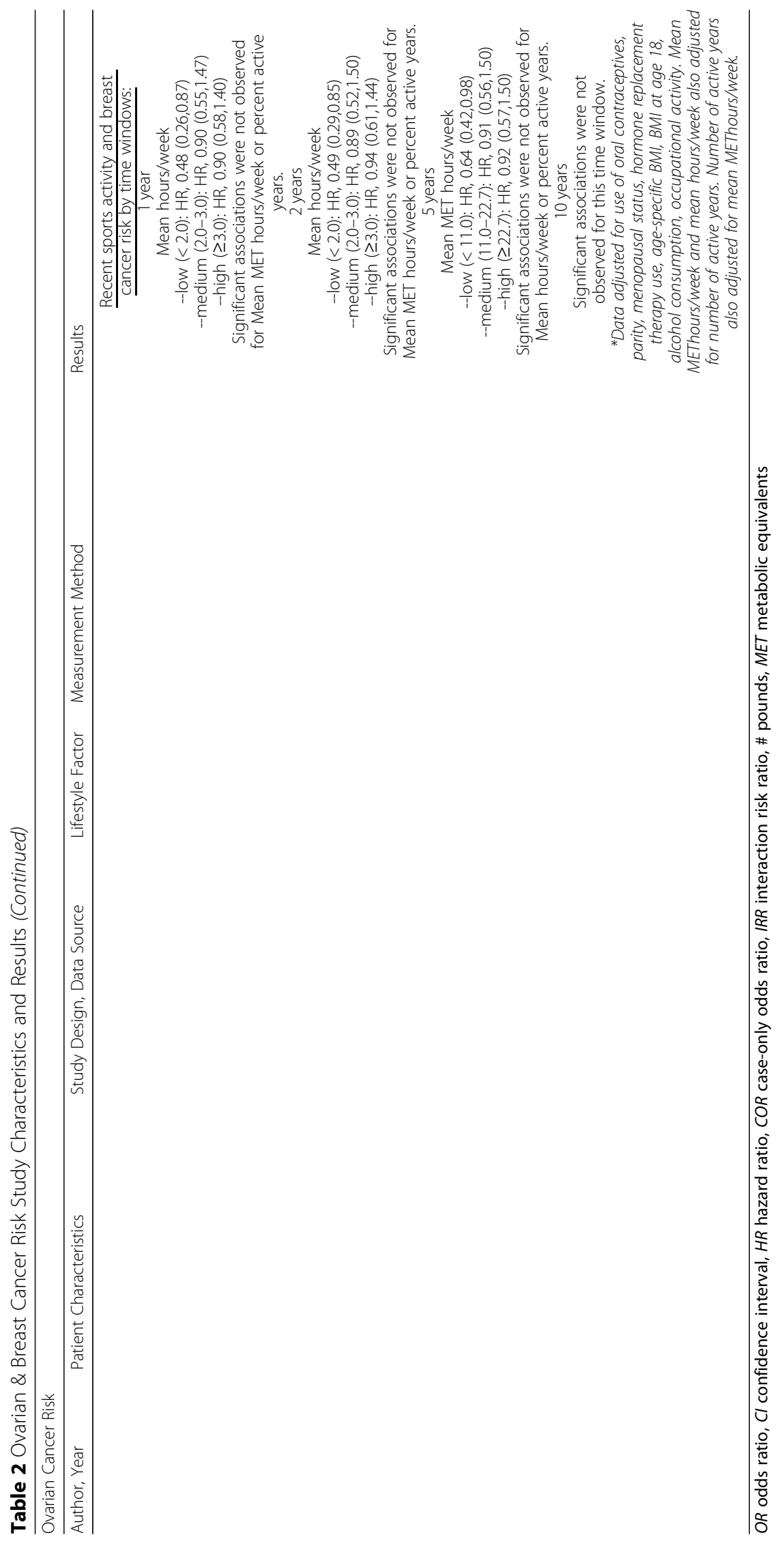


95\% CI 0.13,0.71) was associated with lower risk [24]. Associations were not observed for lower levels of coffee consumption or for any level of decaffeinated coffee [24]. All aforementioned results were adjusted for parity, smoking status, oral contraceptive use, alcohol and BMI at 30-years.

\section{Dietary habits-food/nutrient intake}

Ko and colleagues [12] retrospective cohort assessed dietary intake of vegetables, fruit, meat, seafood, and soybean products, in relation to breast cancer risk among 491 women with $B R C A 1 / 2$ pathogenic germline gene variants collectively and by pathogenic germline gene variant, and adjusted for menarche, caloric intake, years of education, smoking history, alcohol intake, exercise habits and parity. Regarding women with $B R C A 1 / 2$ pathogenic germline gene variants collectively, no association was observed with vegetable, fruit, or seafood intake. Intake of 3-10 meat food-items/day was linked with nearly doubling breast cancer risk (HR 1.97, 95\%CI 1.13,3.4; p-trend $=0.026$ ) [12]. An inverse relationship was observed for soy and breast cancer risk (HR 0.39, 95\%CI $0.19,0.79, \mathrm{p}$-trend $=0.005$ ) [12]. When assessed by $B R C A 1 / 2$ pathogenic germline gene variant, a significant positive relationship was observed for meat intake among women with $B R C A 2$ pathogenic germline gene variant ( $\mathrm{p}$-trend $=0.027$ ), yet only the highest quartile of meat intake was associated with risk (HR 2.48, 95\%CI 1.26,4.89). Moreover, an inverse relationship was observed for soy $(p=0.005)$, but only the highest quartile of soybean-product intake was associated with reduced risk (HR 0.38, 95\%CI 0.16,0.93) [12]. Significant associations were not observed in women with $B R C A 1$ pathogenic germline gene variant.

Case-control studies conducted by Nkondjock and colleagues [31] and Kim and colleagues [27] included assessment of nutrients. Nkondjock and colleagues [31] assessed macro/micronutrient intake, alcohol, and coffee and found that among 89 women with $B R C A 1 / 2$ pathogenic germline gene variants collectively, total energy intake $>2339 \mathrm{kcals} /$ day was associated with nearly tripling breast cancer risk (HR 2.76, 95\%CI 1.10,7.02; p-trend = 0.026), when adjusting for age, maximum lifetime BMI, and PA [31]. Analysis was not conducted by variant. Kim and colleagues [27] assessed folic acid, B6, and B12 supplementation and observed that ever-use of a prenatal supplement was associated with reduced likelihood of breast cancer for 400 women with $B R C A 1 / 2$ pathogenic germline gene variants (OR $0.57,95 \%$ CI $0.34,0.95$ ), when adjusting for age and $B R C A 1 / 2$ pathogenic germline gene variant. When adjusting for age, BRCA1/2 pathogenic germline gene variant, BMI, parity, alcohol consumption and smoking status, consumption of any folic-acid containing supplement, $8.56-89.29 \mathrm{mcg} / \mathrm{d}$ of folic acid supplementation, and $0.02-0.34 \mathrm{mcg} / \mathrm{d}$ of B12 supplementation, was associated with reduced likelihood of breast cancer among women with $B R C A 1 / 2$ pathogenic germline gene variants [27]. When stratified by $B R C A 1 / 2$ pathogenic germline gene variant, significant associations were only revealed for ever-use of any folicacid containing supplement among women with BRCA1 pathogenic germline gene variant [27].

Nkondjock and colleagues [14] conducted a second case-control analysis assessing diet quality among 89 women with $B R C A 1 / 2$ pathogenic germline gene variants collectively. The four diet quality indexes utilized were indicative of dietary patterns and included the following: Alternative Healthy Eating Index(AHEI), Diet Quality Index-Revised(DQI-R), Alternate Mediterranean Diet Index(aMED), Canadian Healthy Eating Index(CHEI). An inverse relationship with breast cancer risk was observed for the DQI-R $(\mathrm{p}$-trend $=0.034)$ and CHEI(p-trend $=0.006$ ); however, only the highest tertile of CHEI was significantly associated with lower breast cancer risk (OR 0.18, 95\%CI 0.05,0.68) after adjusting for age, PA and total energy intake [14].

\section{Weight status/change}

Studies assessing weight management evaluated adulthood and young-adulthood weight status, and adulthood weight change. Moorman and colleagues [23] did not observe effects between BMI one year before diagnosis or at age 18 and breast cancer risk. Among retrospective cohorts, Manders and colleagues [20] observed, among 218 women with $B R C A 1 / 2$ pathogenic germline gene variants, that risk doubled when current weight was $\geq 72 \mathrm{~kg}$ (HR 2.10, 95\%CI 1.23,3.59). These findings were observed in a time-varying Cox-proportional hazard model stratified by gene and birth cohort, clustered for family, and adjusted for parity, menopausal status, hormone replacement therapy, and lifetime sports activity [20]. Among 104 Ashkenazi Jewish women, normal BMI at menarche and 21-years significantly delayed age of onset of breast cancer after adjusting for pro-band decade of birth [17]. Nkondjock and colleagues [31] observed that women with $B R C A 1 / 2$ pathogenic germline gene variants who experienced their maximum BMI at $>43$-years were at a nearly 3 -fold increased risk of breast cancer (OR 2.90, 95\%CI 1.01,8.36).

Among case-control studies, Abbas and colleagues [26] observed a significant association with adulthood overweight/obesity status and increased likelihood of breast cancer (overweight: OR 3.06, 95\%CI 1.36,6.87; obesity: OR 4.09, 95\%CI 1.91,8.75) among 200 women with $B R C A 1 / 2$ pathogenic germline gene variants. In contrast, Qian and colleagues [29] observed a reduction in breast cancer risk with each $5 \mathrm{~kg} / \mathrm{m}^{2}$ increase in BMI at adulthood, young-adulthood, and BMI-GS analyses 
among women with $B R C A 1 / 2$ pathogenic germline gene variants (adulthood: $\mathrm{HR} 0.94,95 \% \mathrm{CI} 0.90,0.98 ; n=6964$; 3331 events; young-adulthood: HR $0.82,95 \% \mathrm{CI} 0.75$, $0.90 ; n=5210 ; 2436$ events; BMI-GS: HR 0.87, 95\%CI $0.76,0.98 ; n=22,588 ; 11,451$ events) [29]. For selfreported BMI, when stratified by $B R C A 1 / 2$ pathogenic germline gene variant, adulthood BMI was inversely associated with breast cancer risk for women with $B R C A 2$ pathogenic germline gene variant, but not $B R C A 1$ pathogenic germline gene variant, and young-adulthood BMI was inversely associated with risk among women with $B R C A 1$ and BRCA2 pathogenic germline gene variants [29]. Similar results were observed when stratified by menopausal status, such that significant inverse associations were observed for adulthood BMI, BMI-GS and premenopausal breast cancer risk, and young adulthood BMI and both pre- and postmenopausal breast cancer risk [29].

Regarding adulthood weight gain, Nkondjock and colleagues [31] observed a positive relationship for weight gain since age $18(\mathrm{p}$-trend $=0.011)$ and $30(\mathrm{p}$-trend $=$ 0.013 ) and breast cancer risk. Women with $B R C A 1 / 2$ pathogenic germline gene variants who gained 12-35 pounds since age 18 exhibited 3.6-fold increased risk (OR 3.63, 95\%CI 1.18,11.22) and women who gained > 35 pounds exhibited 4.6-fold increased risk (OR 4.64, $95 \%$ CI 1.52,14.12) [31]. Since age 30, women who gained 9-20 pounds presented 3.4-fold increased risk (OR 3.43, $95 \%$ CI 1.16,10.14), and women who gained $>20$ pounds displayed 4-fold increased risk (OR 4.11, 95\%CI 1.46, 11.56) [31]. In contrast, Kotsopoulos and colleagues [18] case-control study did not observe a significant relationship for weight gain between ages 18-30 among 1073 women with $B R C A 1 / 2$ pathogenic germline gene variants [31]. Additionally, Manders and colleagues [20] did not observe a relationship between adult weight change and pre- or post-menopausal breast cancer risk.

Interestingly, Kotsopoulos and colleagues [18] considered adulthood weight loss between ages 18-30. A significant association was observed between loss $\geq 10$ pounds and decreased breast cancer risk (OR 0.66, 95\%CI 0.46,0.93) [18]. When assessed by BRCA1/2 pathogenic germline gene variant, a significant association was observed between weight loss of $\geq 10$ pounds and reduced risk of breast cancer among women with $B R C A 1$ but not BRCA2 pathogenic germline gene variant [18].

\section{Physical activity}

Studies assessing PA, evaluated activity across varying time periods, among women with $B R C A 1 / 2$ pathogenic germline gene variants collectively. Among Ashkenazi Jewish women, engagement in PA as a teenager was associated with delayed onset of breast cancer [17].
Nkondjock and colleagues [31] did not observe significant associations between PA variables two years before breast cancer diagnosis and breast cancer risk.

Alternatively, Lammert and colleagues [13] and Pijpe and colleagues [25] evaluated PA over longer periods of time. Lammert and colleagues [13] case-control study among 433 women with $B R C A 1 / 2$ pathogenic germline gene variants assessed PA in adolescence and early adulthood and adjusted analyses for number of children, current BMI, history of oral contraceptive use and/or oophorectomy, and tobacco consumption. Pijpe and colleagues [25] retrospective cohort among 725 women with $B R C A 1 / 2$ pathogenic germline gene variants assessed lifetime sports activity and adjusted for oral contraceptives, parity, menopausal status, hormone replacement therapy, age-specific BMI, BMI at age 18, alcohol consumption, occupational activity. In certain analyses, mean metabolic equivalent (MET)-hours/week and mean hours/week were adjusted for number of active years, and number of active years were also adjusted for mean MET-hours/week.

Lammert and colleagues [13] assessed moderate, vigorous, and total activity in MET-hours/week in adolescence, young adulthood, and overall. Analysis was also stratified by menopausal status at diagnosis. The only association observed was for the highest quartile of moderate activity in adolescence, $>25.88$ MET-hours/week, in relation to premenopausal breast cancer risk (HR 0.62, 95\%CI 0.40,0.96) [13].

Pijpe and colleagues [25] assessed lifetime sports activity overall, before and after age 30 , and in time windows (one-year, two-, five-, and 10-years) before age 35. Overall, 11-22.7 MET-hours/week of sports activity was associated with a $41 \%$ reduction in risk (HR $0.59,95 \% \mathrm{CI}$ $0.36,0.95$ ), whereas $\geq 22.7$ MET-hours/week was not associated with reduced risk (HR 0.77, 95\%CI 0.8,1.24) [25]. When never engaging in sports activity was the reference, significant associations were not observed [25].

Before age 30, when the lowest sports activity category was used as the reference, 11-22.7 and $\geq 22.7$ mean MET-hours/week was associated with a $40 \%$ reduction in breast cancer risk $[9,25]$. Associations were not observed when never-engaging in sports activity was used as the reference category. In contrast, after age 30, everengaging in sports activity was associated with a $37 \%$ reduction in breast cancer risk (HR 0.63, 95\%CI 0.44,0.91 [25]. When never-engaging in sports activity was the reference category, significant associations were only observed for the lowest category (least amount of activity) of each variable [32].

Table 3 provides a summary of results for diet, weight, and PA in relation to ovarian and breast cancer risk among women with $B R C A 1 / 2$ pathogenic germline gene variants. 
Table 3 Diet/Weight/Physical Activity and Ovarian \& Breast Cancer Risk in BRCA1/2 Pathogenic Germline Gene Variant Carriers

\begin{tabular}{|c|c|c|}
\hline $\begin{array}{l}\text { Cancer } \\
\text { Type }\end{array}$ & $\begin{array}{l}\text { Energy Balance-Related } \\
\text { Factors }\end{array}$ & Major Findings \\
\hline \multirow{2}{*}{$\begin{array}{l}\text { Ovarian } \\
\text { Cancer }\end{array}$} & Dietary Habits & - 1 study; No association between regular coffee consumption and ovarian cancer risk in BRCA1 (Gronwald, 2006) \\
\hline & $\begin{array}{l}\text { Weight Status/Weight } \\
\text { Change }\end{array}$ & $\begin{array}{l}\text { - } 2 \text { studies (McGee, 2012; Qian, 2019) } \\
\text { - No association between weight change in adulthood and ovarian cancer risk in BRCA1 \& BRCA2 (McGee, 2012) } \\
\text { - Significant association between higher BMl and premenopausal ovarian cancer risk BRCA1 \& BRCA2 (Qian, 2019) }\end{array}$ \\
\hline \multirow[t]{3}{*}{$\begin{array}{l}\text { Breast } \\
\text { Cancer }\end{array}$} & Dietary Habits & 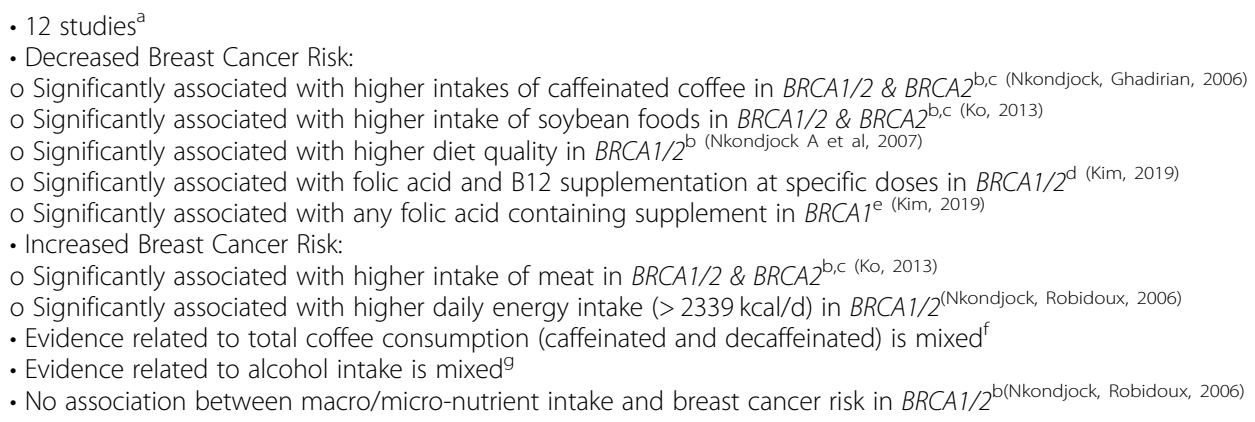 \\
\hline & $\begin{array}{l}\text { Weight Status/Weight } \\
\text { Change }\end{array}$ & 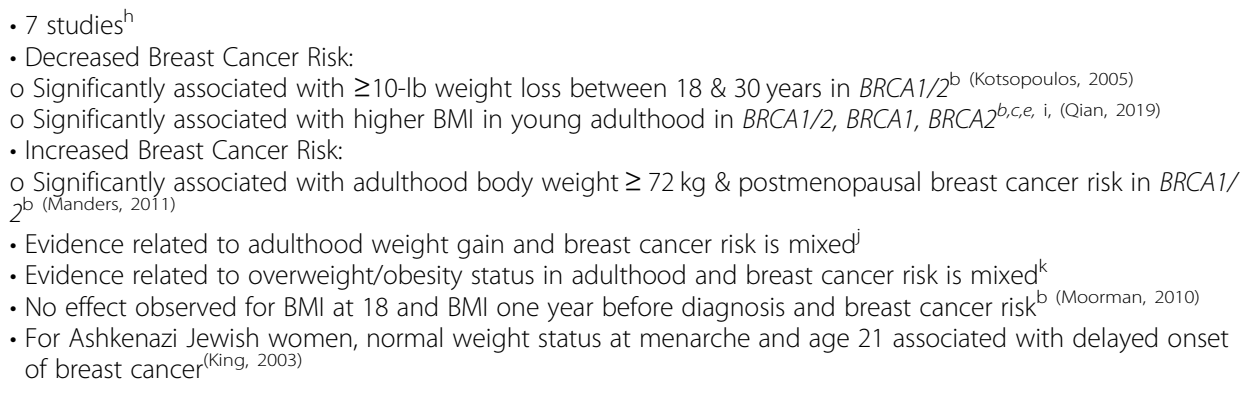 \\
\hline & Physical Activity & $\begin{array}{l}\text { - } 4 \text { studies } \\
\text { - Decreased Breast Cancer Risk: } \\
\text { o Significantly associated with activity during adolescence, high levels of activity before age } 30 \text {, and lower } \\
\text { levels of activity after age } 30 \text { in BRCA1/2 } \\
\text { - No assommert, 2018; Pijpe, 2010) } \\
\text { - For Ashkenazi for activity two years before diagnosis and breast cancer risk in } B R C A 1 / 2^{\text {b(Nkondjock,Robidoux, 2006) }} \\
\text { breast cancer (King, 2003) }\end{array}$ \\
\hline
\end{tabular}

\section{Ib pound; $B M I$ body mass index}

${ }^{\text {a }}$ Seven studies assessed alcohol intake ( 6 exclusive to alcohol, 1 included alcohol with nutrient intake), two assessed coffee intake, one assessed supplement use (folic acid, B6, B12), one assessed food group intake, one assessed nutrient intake (and included alcohol), one assessed diet quality

${ }^{\mathrm{b}}$ Both $B R C A 1$ and $B R C A 2$ pathogenic germline gene variants combined in the analysis

'Only $B R C A 2$ pathogenic germline gene variant in the analysis

${ }^{\mathrm{d}}$ Folic acid:8.56- $\leq 89.29 \mathrm{mcg} / \mathrm{d} ; \mathrm{B} 12: 0.02-\leq 0.34 \mathrm{mcg} / \mathrm{d}$

eOnly BRCA1pathogenic germline gene variant in the analysis

${ }^{f}$ One study observed no association(Gronwald, 2006) and one study observed OR0.51 $(0.26,0.98)$ for total coffee consumption in relation to breast cancer risk(Nkondjock, Ghadirian, 2006)

${ }^{9}$ Three studies observed no association between alcohol intake and breast cancer risk in BRCA1/2 variants collectively(Cybulski, 2015; Nkondjock, Robidoux, 2006; Lecarpentier 2011), one study observed an association in BRCA1 but not BRCA2 when tobacco use was included as an interaction(Lecarpentier, 2011), one study observed an association in BRCA1 but not BRCA2(Dennis, 2010), one study observed a weak effect of alcohol when comparing breast cancer survivors compared to survivors without $B R C A$, no effect was observed for BRCA2(Moorman, 2010), one study observed an association in BRCA2 but not BRCA1(McGuire, 2006), one study observed an effect for alcohol when comparing survivors with $B R C A 2$ to survivors without $B R C A$, but an effect was not observed in $B R C A 1$ (Dennis, 2011)

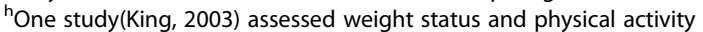

'Association applies to pre- and post-menopausal breast cancer risk

jOne study observed a significant association with weight gain since age 18 and 30 and increased breast cancer risk for BRCA1/2 variants (Nkondjock, Robidoux 2006), one study did not observe a significant association with 10-20 or $>20 \mathrm{lb}$. weight gain between the ages of 18 and 30 for $B R C A 1 / 2$ variants collectively and by variant, and when age at diagnosis was between 30 and 40 years or $>40$ years (Kotsopoulos, 2005)

kOne study observed a significant inverse association between breast cancer risk and self-reported adulthood overweight/obesity and genetically scored overweight/obesity (Qian, 2019), one study observed a significant positive association between breast cancer risk and adulthood overweight/obesity(Abba, 2019), one study observed a significant positive association between breast cancer risk and adulthood overweight/obesity beyond age 43(Nkondjock, Robidoux, 2006), one study observed a significant positive association with postmenopausal breast cancer risk and adulthood body weight $\geq 72 \mathrm{~kg}(\mathrm{Manders,} 2011$ )

\section{Discussion}

This systematic review did not find cohesive evidence supporting the need for tailored recommendations regarding dietary habits, weight management and PA for ovarian and breast cancer risk-reduction among women with $B R C A 1$ or $B R C A 2$ pathogenic germline gene variants. Regarding ovarian cancer risk, there was limited evidence supporting relationships between dietary habits and 
ovarian cancer incidence. The limited findings related to weight management and premenopausal ovarian cancer risk are similar to findings observed in the general population, which suggests probable relationship between body fatness and increased risk of ovarian cancer [33].

Among the general population, evidence is probable and convincing that alcohol intake increases pre- and postmenopausal breast cancer risk, respectively [34]. Thus current cancer prevention guidelines recommend limiting alcohol [34]. Among women with BRCA1/2 pathogenic germline gene variants collectively and by $B R C A 1 / 2$ pathogenic variant, evidence is mixed [11, 15, $16,19,22,23]$. Notably, some studies demonstrated no association between alcohol intake and breast cancer risk among women with $B R C A 1 / 2$ pathogenic germline gene variants collectively $[15,19,31]$, while others observed a reduction in risk with alcohol intake in women with $B R C A 1$ pathogenic germline gene variants $[16,23]$ and $B R C A 2$ pathogenic germline gene variants [22]. Considering the known potential harms associated with alcohol, stronger and more consistent evidence is needed to support more liberal guidelines for alcohol use in women with $B R C A 1 / 2$ pathogenic germline gene variants.

Evidence is limited related to food/nutrient intake and breast cancer risk among women with $B R C A 1 / 2$ pathogenic germline gene variants $[12,14,27,31]$. An association was not observed with vegetable intake [12], and findings for micronutrients are mixed, pending the nutrient $[27,31]$. Among the general population, evidence is limited and inconclusive regarding the relationship between nonstarchy vegetables, nutrients, and breast cancer risk [34].

Evidence is also mixed for adulthood weight gain [18, $20]$ and adulthood weight status [20, 26, 29, 31]. Among the general population, evidence is probable that overweight/obesity in young adulthood decreases pre- and postmenopausal breast cancer risk, and overweight/ obesity in adulthood increases postmenopausal breast cancer risk [34]. Whether weight management recommendations should differ for women with BRCA1/2 pathogenic germline gene variants remains elusive.

Regarding PA, activity in adolescence and lifetime activity appear to have some association with breast cancer risk-reduction among women with $B R C A 1 / 2$ pathogenic germline gene variants collectively $[13,25]$. This notion is supported by evidence from the general population, such that it is probable that PA, regardless of intensity, reduces postmenopausal risk and vigorous-intensity activity reduces premenopausal risk [34]. Thus, activity recommendations should remain consistent with recommendations for the general population.

This is the first study to our knowledge to systematically evaluate whether tailored recommendations related to dietary habits, weight management and PA may be effective in reducing ovarian and breast cancer risk among women with $B R C A 1 / 2$ pathogenic germline gene variants. We consider the following factors limitations of the current state of evidence: small number of studies for both ovarian and breast cancer risk in this high risk population, especially when considering the available large epidemiological studies that have established associations of lifestyle factors among the general population; heterogeneity in methods to evaluate lifestyle factors; inconsistent confounding factors; no data evaluating hormone receptor status; limited data evaluating by gene variant and menopausal status. Considering these limitations, notably the heterogeneity of the current evidence, inability to separate analyses by $B R C A 1 / 2$ pathogenic germline gene variant, and retrospective nature of the majority of studies conducted, it is difficult to determine the extent of which recommendations for lifestyle factors should differ for this higher risk population. Future observational studies should address these limitations, specifically prospective, larger cohort studies enabling one to assess risk for these factors by gene variant.

\section{Conclusions}

Among women with $B R C A 1 / 2$ pathogenic germline gene variants, there is insufficient evidence for recommendations related to dietary habits or weight management and ovarian cancer risk. Pertaining to breast cancer, there is not enough evidence to suggest variation from current recommendations for the general population for dietary habits or weight management. There is no evidence to suggest that risk association related to physical activity differed from the general population; therefore, recommendations for physical activity should remain the same.

\section{Supplementary information}

Supplementary information accompanies this paper at https://doi.org/10. 1186/s13053-020-0137-1.

Additional file 1. Search Strategy.

\section{Abbreviations}

AHEl: Alternative Healthy Eating Index; aMED: Alternate Mediterranean Diet Index; BMI: Body Mass Indez; BMI-GS: Calculated Body Mass Index- Genetic Score; CHEl: Canadian Healthy Eating Index (CHEl); COR: Case-Only Odds Ratio; DQI-R: Diet Quality Index-Revised; IRR: Interaction Risk Ratio; MET: Metabolic Equivalent; PA: Physical Activity; PRISMA: Preferred Reporting Items for Systematic Reviews and Meta-Analyses

\section{Acknowledgements \& Footnotes}

Not applicable

\section{Authors' contributions}

KBE conceptualized the paper. AMC, KJK, KBE and LAG developed the search strategy. KJK conducted the search, de-duplicated the data, and organized findings per PRISMA guidelines for AMC and LAG review. AMC and LAG conducted both rounds of review (abstract and full text reviews). AMC wrote the manuscript. All authors contributed to data interpretation and editing of the manuscript. All authors read and approve the final manuscript. 


\section{Author information}

KJK is a research medical librarian who specializes in systematic reviews and meta-analyses.

\section{Funding}

Research reported in this publication was supported by the National Cancer Institute of the National Institutes of Health under Award Number R25CA057730 (Pl: Shine Chang, PhD), by the Center for Energy Balance in Cancer Prevention and Survivorship, Duncan Family Institute for Cancer Prevention and Risk Assessment, and by MRSG-13-145-01 from the American Cancer Society.

\section{Availability of data and materials}

Not applicable.

\section{Ethics approval and consent to participate}

Not applicable.

\section{Consent for publication}

Not applicable.

\section{Competing interests}

The authors declare that they have no competing interests.

\section{Author details}

1Department of Behavioral Science, The University of Texas MD Anderson Cancer Center, P.O. Box 301439, Unit 1330, Houston, TX 77030-1439, USA. ${ }^{2}$ Cancer Control and Population Sciences Program, Huntsman Cancer Institute, Salt Lake City, UT, USA. ${ }^{3}$ Department of Health, Kinesiology, and Recreation, The University of Utah, Salt Lake City, UT, USA. ${ }^{4}$ Research Medical Library, The University of Texas MD Anderson Cancer Center, Houston, TX 77030, USA. ${ }^{5}$ Department of Family and Community Medicine, College of Medicine- Tucson, University of Arizona, Tucson, AZ 85724, USA.

${ }^{6}$ Department of Clinical Cancer Prevention, The University of Texas MD Anderson Cancer Center, Houston, TX 77030, USA. 'Department of Breast Medical Oncology, The University of Texas MD Anderson Cancer Center, Houston, TX 77030, USA. ${ }^{8}$ Department of Surgical Oncology, The University of Texas MD Anderson Cancer Center, Houston, TX 77030, USA. ${ }^{9}$ Department of Health Disparities Research, The University of Texas MD Anderson Cancer Center, Houston, TX 77030, USA. ${ }^{10}$ Department of Gynecologic Oncology and Reproductive Medicine, The University of Texas MD Anderson Cancer Center, Houston, TX 77030, USA.

Received: 1 December 2019 Accepted: 26 February 2020

Published online: 07 March 2020

\section{References}

1. Kuchenbaecker KB, Hopper JL, Barnes DR, Phillips KA, Mooij TM, Roos-Blom $\mathrm{MJ}$, et al. Risks of breast, ovarian, and contralateral breast Cancer for BRCA1 and BRCA2 mutation carriers. JAMA. 2017;317(23):3402-16.

2. Bermejo-Pérez MJ, Márquez-Calderón S, Llanos-Méndez A. Effectiveness of preventive interventions in BRCA1/2 gene mutation carriers: a systematic review. Int J Cancer. 2007;121(2):225-31.

3. Friebel $\mathrm{T}$, Domchek $\mathrm{S}$, Rebbeck T. Modifiers of cancer risk in BRCA1 and BRCA2 mutation carriers: systematic review and meta-analysis. J Natl Cancer Inst. 2014;106(6):dju091.

4. Chang-Claude J, Becher H, Eby N, Bastert G, Wahrendorf J, Hamann U. Modifying effect of reproductive risk factors on the age at onset of breast cancer for German BRCA1 mutation carriers. J Cancer Res Clin Oncol. 1997; 123(5):272-9.

5. Jiang $W, W u Y$, Jiang $X$. Coffee and caffeine intake and breast cancer risk: an updated dose-response meta-analysis of 37 published studies. Gynecol Oncol. 2013;129(3):620-9.

6. McDonald JA, Goyal A, Terry MB. Alcohol intake and breast cancer risk: weighing the overall evidence. Curr Breast Cancer Rep. 2013;5(3):208-21.

7. Pettapiece-Phillips R, Narod SA, Kotsopoulos J. The role of body size and physical activity on the risk of breast cancer in BRCA mutation carriers. Cancer Causes Control. 2015;26(3):333-44.

8. Liberati A, Altman D, Tetzlaff J, Mulrow C, Gotzsche P, loannidis J, et al. The PRISMA statement for reporting systematic reviews and meta-analyses of studies that evaluate health care interventions: explanation and elaboration. J Clin Epidemiol. 2009:62(10):e1-34.

9. Schembre S, Liao Y, Robertson M, Dunton G, Kerr J, Haffey M, et al. Just-in-time feedback in diet and physical activity interventions: systematic review and practical design framework. J Med Internet Res. 2018;20(3):e106.

10. Thomas B, Ciliska D, Dobbins M, Micucci S. A process for systematically reviewing the literature: providing the research evidence for public health nursing interventions. Worldviews Evid-Based Nurs. 2004;1(3):176-84.

11. Dennis J, Krewski D, Côté FS, Fafard E, Little J, Ghadirian P. Breast cancer risk in relation to alcohol consumption and BRCA gene mutations - a case-only study of gene-environment interaction. Breast J. 2011;17(5):477-84.

12. Ko KP, Kim SW, Ma SH, Park B, Ahn Y, Lee JW, et al. Dietary intake and breast cancer among carriers and noncarriers of BRCA mutations in the Korean hereditary breast Cancer study. Am J Clin Nutr. 2013;98(6):1493-501.

13. Lammert J, Lubinski J, Gronwald J, Huzarski T, Armel S, Eisen A, et al. Physical activity during adolescence and young adulthood and the risk of breast cancer in BRCA1 and BRCA2 mutation carriers. Breast Cancer Res Treat. 2018;169(3):561-71.

14. Nkondjock A, Ghadirian P. Diet quality and BRCA-associated breast cancer risk. Breast Cancer Res Treat. 2007;103(3):361-9.

15. Cybulski C, Lubinski J, Huzarski T, Lynch HT, Randall SA, Neuhausen SL, et al. Prospective evaluation of alcohol consumption and the risk of breast cancer in BRCA1 and BRCA2 mutation carriers. Breast Cancer Res Treat. 2015;03.

16. Dennis J, Ghadirian P, Little J, Lubinski J, Gronwald J, Kim-Sing C, et al. Alcohol consumption and the risk of breast cancer among BRCA1 and BRCA2 mutation carriers. Breast. 2010;19(6):479-83.

17. King MC, Marks JH, Mandell JB. Breast and ovarian Cancer risks due to inherited mutations in BRCA1 and BRCA2. Science. 2003;302(5645):643-6.

18. Kotsopoulos J, Olopado Ol, Ghadirian P, Lubinski J, Lynch HT, Isaacs C, et al. Changes in body weight and the risk of breast cancer in BRCA1 and BRCA2 mutation carriers. Breast Cancer Res. 2005;7(5):R833-43.

19. Lecarpentier J, Noguès C, Mouret-Fourme E, Stoppa-Lyonnet D, Lasset C, Caron $\mathrm{O}$, et al. Variation in breast cancer risk with mutation position, smoking, alcohol, and chest X-ray history, in the French national BRCA1/2 carrier cohort (GENEPSO). Breast Cancer Res Treat. 2011;130(3):927-38.

20. Manders P, Pijpe A, Hooning MJ, Kluijt I, Vasen HF, Hoogerbrugge N, et al. Body weight and risk of breast cancer in BRCA1/2 mutation carriers. Breast Cancer Res Treat. 2011;126(1):193-202.

21. McGee J, Kotsopoulos J, Lubinski J, Lynch HT, Rosen B, Tung N, et al. Anthropometric measures and risk of ovarian cancer among BRCA1 and BRCA2 mutation carriers. Obesity (Silver Spring). 2012;20(6):1288-92.

22. McGuire V, John EM, Felberg A, Haile RW, Boyd NF, Thomas DC, et al. No increased risk of breast cancer associated with alcohol consumption among carriers of BRCA1 and BRCA2 mutations ages $<50$ years. Cancer Epidemiol Biomark Prev. 2006;15(8):1565-7.

23. Moorman PG, Iversen ES, Marcom PK, Marks JR, Wang F, Lee E, et al. Evaluation of established breast cancer risk factors as modifiers of BRCA1 or BRCA2: a multi-center case-only analysis. Breast Cancer Res Treat. 2010; 124(2):441-51.

24. Nkondjock A, Ghadirian P, Kotsopoulos J, Lubinski J, Lynch H, Kim-Sing C, et al. Coffee consumption and breast cancer risk among BRCA1 and BRCA2 mutation carriers. Int J Cancer. 2006;1 18(1):103-7.

25. Pijpe A, Manders P, Brohet RM, Collee JM, Verhoef S, Vasen HF, et al. Physical activity and the risk of breast cancer in BRCA1/2 mutation carriers. Breast Cancer Res Treat. 2010;120(1):235-44.

26. Abbas S, Siddique A, Shahid N, Khan RT, Fatima W. Breast cancer risk associated with BRCA1/2 variants in the Pakistani population. Breast Cancer. 2019;26(3):365-72.

27. Kim SJ, Zhang CXW, Demsky R, Armel S, Kim YI, Narod SA, et al. Folic acid supplement use and breast cancer risk in BRCA1 and BRCA2 mutation carriers: a case-control study. Breast Cancer Res Treat. 2019;174(3):741-8.

28. Qian F, Rookus MA, Leslie G, Risch HA, Greene MH, Aalfs CM, et al. Mendelian randomisation study of height and body mass index as modifiers of ovarian cancer risk in 22,588 BRCA1 and BRCA2 mutation carriers. Br J Cancer. 2019;121(2):180-92.

29. Qian F, Wang S, Mitchell J, McGuffog L, Barrowdale D, Leslie G, et al. Height and body mass index as modifiers of breast Cancer risk in BRCA1/2 mutation carriers: a Mendelian randomization study. J Natl Cancer Inst. 2019;111(4):350-64. 
30. Gronwald J, Byrski T, Huzarski T, Cybulski C, Sun P, Tulman A, et al. Influence of selected lifestyle factors on breast and ovarian cancer risk in BRCA1 mutation carriers from Poland. Breast Cancer Res Treat. 2006;95(2):105-9.

31. Nkondjock A, Robidoux A, Paredes Y, Narod SA, Ghadirian P. Diet, lifestyle and BRCA-related breast cancer risk among French-Canadians. Breast Cancer Res Treat. 2006;98(3):285-94.

32. Lauby-Secretan B, Scoccianti C, Loomis D, Grosse Y, Bianchini F, Straif K, et al. Body fatness and cancer- viewpoint of the IARC working group. N Engl J Med. 2016;375(8):794-8.

33. World Cancer Research Fund International/American Institute for Cancer Research. Continuous update project expert report 2018. Diet, nutrition, physical activity and ovarian cancer. 2018;Available at dietandcancerreport. org.

34. World Cancer Research Fund International/American Institute for Cancer Research. Continuous update project expert report 2018. Diet, nutrition, physical activity and breast cancer survivors. 2018;Available at dietandcancerreport.org.

\section{Publisher's Note}

Springer Nature remains neutral with regard to jurisdictional claims in published maps and institutional affiliations.

Ready to submit your research? Choose BMC and benefit from:

- fast, convenient online submission

- thorough peer review by experienced researchers in your field

- rapid publication on acceptance

- support for research data, including large and complex data types

- gold Open Access which fosters wider collaboration and increased citations

- maximum visibility for your research: over $100 \mathrm{M}$ website views per year

At $\mathrm{BMC}$, research is always in progress.

Learn more biomedcentral.com/submissions 